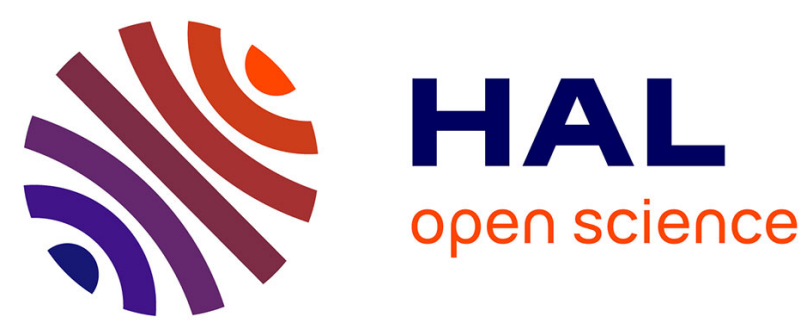

\title{
Rifting and shallow-dipping detachments, clues from the Corinth Rift and the Aegean
}

\author{
Laurent Jolivet, Loic Labrousse, Philippe Agard, Olivier Lacombe, Vivien \\ Bailly, Emmanuel Lecomte, Frédéric Mouthereau, Caroline Mehl
}

\section{- To cite this version:}

Laurent Jolivet, Loic Labrousse, Philippe Agard, Olivier Lacombe, Vivien Bailly, et al.. Rifting and shallow-dipping detachments, clues from the Corinth Rift and the Aegean. Tectonophysics, 2010, 483 (3-4), pp.287-304. 10.1016/j.tecto.2009.11.001 . insu-00448474

\section{HAL Id: insu-00448474 https://hal-insu.archives-ouvertes.fr/insu-00448474}

Submitted on 19 Jan 2010

HAL is a multi-disciplinary open access archive for the deposit and dissemination of scientific research documents, whether they are published or not. The documents may come from teaching and research institutions in France or abroad, or from public or private research centers.
L'archive ouverte pluridisciplinaire HAL, est destinée au dépôt et à la diffusion de documents scientifiques de niveau recherche, publiés ou non, émanant des établissements d'enseignement et de recherche français ou étrangers, des laboratoires publics ou privés. 


\section{Rifting and shallow-dipping detachments, clues from the Corinth Rift and the Aegean}

Laurent Jolivet ${ }^{1,2}$, Loïc Labrousse ${ }^{1}$, Philippe Agard ${ }^{1}$, Olivier Lacombe ${ }^{1}$, Vivien Bailly ${ }^{1}$, Emmanuel Lecomte ${ }^{1}$, Frédéric Mouthereau ${ }^{1}$, Caroline Mehl ${ }^{3}$

${ }^{1}$ ISTEP, UPMC-Paris6, UMR 7193, T 46-00 E1, 4 Place Jussieu, 75252 Paris cedex 05

${ }^{2}$ Now at: ISTO, UMR 6113, Université d'Orléans 1A, Rue de la Férollerie, 45071 Orléans Cedex 2, France

${ }^{3}$ Ecole des Mines de Paris, Centre de Géosciences, 35 rue Saint Honoré, 77300 Fontainebleau France

Keywords: Aegean, Corinth, rifting, post-orogenic extension, detachment, Phyllite-Quartzite

Abstract : The Corinth Rift is superimposed on the Hellenic nappe stack that formed at the expense of the Apulian continental crust above the subducting African slab. Extension started in the Pliocene and the major steep normal faults that control the geometry of the present-day rift were born very recently, some $600 \mathrm{Kyrs}$ ago only. They root into a shallowdipping zone of microseismicity recorded near the base of the upper crust. The significance of this seismogenic zone is debated. Considering the northward dip of the zone of microseismicity, the depth of microearthquakes and their focal mechanisms, we observe a strong similarity with the northern Cycladic detachments in terms of expected pressure, temperature conditions and kinematics. We herein show (1) that the formation of the Corinth Rift can be considered a part of a continuum of extension that started some 30-35 Ma in the Aegean and that was recently localised in a more restricted area, (2) that the present-day structure and kinematics of the Corinth Rift can be explained with a series of decollements relayed by steeper ramps that altogether formed a mechanically weak, crustal-scale detachment, and (3) that the deformation, fluid behaviour and metamorphic features seen in the northern Cycladic metamorphic core complexes can be good analogues of the processes at work below the Corinth Rift. 


\section{Introduction.}

The Gulf of Corinth (Figure 1) is the fastest-spreading documented intracontinental rift on Earth. Geodetically measured extension amounts to $1.5 \mathrm{~cm} / \mathrm{yr}$ and is mainly accommodated within the offshore section (Billiris et al., 1991; Briole et al., 2000). This rift is however part of a wider zone of extension distributed over the whole Aegean domain and has been considered the most recent event of a continuum of extension with a localization through time (Jolivet et al., 1994a; Jolivet, 2001).

Post-orogenic extension started in the Aegean region at least $30 \mathrm{Ma}$ ago (Jolivet and Faccenna, 2000). Extension was first distributed over a large domain from 30-35 Ma to approximately $5 \mathrm{Ma}$ and was marked by the formation of the Cycladic metamorphic core complexes all over the Aegean Sea (Lister et al., 1984; Gautier and Brun, 1994a; b; Jolivet et al., 1994a; Jolivet and Patriat, 1999). It then tended to localize in western Turkey as well as near the tip of the North Anatolian Fault (NAF), either in the North Aegean Trough or in a series of grabens (Volos, Corinth) in a wide zone of extension and block rotation that bounds the Aegean block to the west (McKenzie, 1978; Jackson, 1994; Armijo et al., 1996).

A debate exists about the respective causes of these two successive extensional regimes. One view is to disconnect the two regimes, the first one being caused by retreat of the Hellenic slab and the second by the propagation of the NAF in the Pliocene, with the Corinth Rift accommodating the strike-slip motion by extension and rotation of the fault system (Taymaz et al., 1991; Armijo et al., 1996; 1999). The localisation of the Corinth Rift near the termination of the NAF, a high rate of extension and modelling of the GPS velocity field (Flerit et al., 2004) support this interpretation. The distribution of rotations indicated by paleomagnetic studies is however not simple and recent data suggest that the southern margin of the Gulf has rotated counterclockwise since the Pliocene (Mattei et al., 2004) instead of a simple clockwise rotation expected in a dextral shearing environment.

An alternative view is to consider that the ultimate cause of extension (slab retreat and crustal collapse) has not changed and that the propagation of the NAF or some other cause has simply localised extension near its termination (Jolivet, 2001). In that sense the Gulf of Corinth would be a precursor of a future metamorphic core complex similar to those of the Cyclades or the Aegean region (Chéry, 2001; Jolivet, 2001). Several lines of arguments 
support this alternative interpretation: (1) the southward velocity increase shown by GPS data may suggest that the engine is a traction toward the south induced by slab retreat and not only the indentation of Arabia (Jolivet, 2001; Kreemer and Chamot-Rooke, 2004), (2) the overall asymmetry and the detailed kinematics of the Corinth Rift, including the likely presence of a active shallow-north dipping decollement at depth below the offshore section of the rift near the brittle-ductile transition (King et al., 1985; Rigo et al., 1996) and onshore observations (Sorel, 2000), are reminiscent of the geometry and kinematics of the Oligo-Miocene extensional metamorphic domes observed in the Cyclades. Offshore seismic investigations, although they provide rather detailed images of the uppermost crustal structure, have also led to opposing conclusions. For Sachpazi et al. (2003), Pi Alperin et al. (2004) or Taylor et al. (2003) reflections are compatible with the presence of a shallow north-dipping detachment, while Bell et al. (2008; 2009) argue instead in favor of a more symmetric extension and the absence of a detachment, that is not required to explain observed structures. One of the keyquestions is the geometrical relations between the onshore detachment described by Sorel (2000) and the zone of microseismicity recorded at depth.

In this paper, we 1) review available data on the Corinth rift and provide a balanced, crustal-scale restoration of the rift, 2) explore the similarities and differences between the Corinth Rift and the Cyclades in terms of geometry, kinematics and pressure and temperature conditions, and 3) assess the potential of Aegean metamorphic core complexes as analogues of the deformation presently at work below the Corinth Rift.

1. Crustal-scale extension: normal faults versus post-orogenic detachments

Extension is commonly accommodated by two kinds of structures: steeply-dipping normal faults bounding grabens (Jackson and White, 1989) and shallow-dipping detachments below which metamorphic core complexes were exhumed (see Lister et al., 1984; Gautier and Brun, 1994a, for the Cyclades); figure 2 summarizes this debate for the Aegean region and the Corinth Rift. The most obvious structures in the Corinth Rift are the steep active normal faults that shape the morphology of the southern margin (Armijo et al., 1996). The distribution of these normal faults is often asymmetrical, one set of faults being predominant, thus suggesting an asymmetry of deformation at crustal or lithospheric scale (Colletta et al., 1987). 
Models of asymmetric extension have been developed in the 80's after the discovery of shallow-dipping normal faults in the Basin and Range Province. The debate then became focussed on the degree of asymmetry, at crustal or lithospheric scale (Wernicke, 1981; Brun and Choukroune, 1983; Davis, 1983; Coney and Harms, 1984; Lister et al., 1986; Klemperer, 1988). Seismological studies and deep seismic profiles have shown that normal faults generally do not reach deeper than 10-15 km (Klemperer, 1988; Jackson and White, 1989) and that they may be relayed at depth by shallow-dipping ductile shear zones (Brun et al., 1992). A model of the extending continental crust has thus emerged with an upper crust deforming with steeply-dipping faults rooting on more or less shallow-dipping shear zones in the middle and lower crust, and a lithospheric mantle deforming ductilely in a more diffuse manner. By contrast, several classes of models of extension of the continental crust use steeply-dipping normal faults in the upper crust (Jackson and White, 1989), relayed at depth by a ductile flow in the lower crust (Kusznir and Park, 1987). In this case no detachment is required in the middle crust.

Field studies have documented the existence of shallow-dipping normal faults separating units with different metamorphic evolutions with a large pressure gap across, the hangingwall recording much lower pressures than the footwall (Wernicke, 1981; 1992; 1995; Platt, 1986; Burchfiel et al., 1987; Lister and Davis, 1989; Abers, 1991; Jolivet et al., 1994a; 1998a; Taylor and Huchon, 2002). Shallow-dipping normal faults may be the late evolution of a ductile extensional shear zone during the exhumation from ductile to brittle conditions (Lister and Davis, 1989; Mehl et al., 2005).

On the other hand, studies of earthquakes on normal faults have shown that the largest events nucleate on the steep fault plane seen at the surface, and that one of the nodal planes is compatible with that same fault (Jackson and White, 1989). This suggests that normal faults are steep and planar down to the brittle-ductile transition. It was noted at that time that these studies did not preclude the existence of shallow-dipping normal faults, but they had to be seismically silent and thus weak. This weakness is indeed attested by studies of shallowdipping detachments where fluid circulation plays an important role and can be an agent of rock weakening (Morrison and Anderson, 1998; Famin et al., 2004b; 2005).

As exhumation of $\mathrm{HP}$ metamorphic rocks and post-orogenic extension both involve large-scale detachments, and the use of the term "extension" in both situations is often 
misleading, we propose the following terminology: "extension” is only used when the activity of normal faults or extensional ductile shear zones has led to crustal thinning (in classical rifting for instance). We thus use "post-orogenic extension" to describe the formation of extensional metamorphic domes in the Cyclades during the Oligo-Miocene; instead, when detachments participate to the exhumation of metamorphic rocks but do not lead to crustal thinning we propose to use "syn-orogenic detachment tectonics".

Low-angle normal faults have been described in different geological situations including post-orogenic extension, exhumation of HP-LT metamorphic rocks and even intraoceanic rifting (Wernicke, 1981; 1995; Lister et al., 1984; Avigad and Garfunkel, 1989; Abers et al., 1997; Axen et al., 1999; Hayman et al., 2003; Collettini and Holdsworth, 2004; Garcès and Gee, 2007). Such low-angle normal faults are often referred to as detachments. In this acception a detachment is a shallow-dipping normal fault, cutting down-section across a stratigraphic pile or a nappe stack. Motion along the detachment results in the direct juxtaposition of a superficial (usually non metamorphosed) unit on top of a deep metamorphic unit. High-pressure and low-temperature (HP-LT) metamorphic complexes are often topped by shallow-dipping detachments that were active during the formation of the nappe stack (Platt, 1986; Jolivet et al., 1998b), whereas some of the HT metamorphic domes capped by similar detachments were exhumed during post-orogenic crustal-scale extension. The firstorder similarity of the two types of detachments in the field often renders the distinction difficult. The Aegean Sea (figure 3) and its neighbourhood is a region where both processes were recorded in sequence.

2.

\section{Geodynamic setting and published models}

The Aegean Sea (figure 3) is a backarc basin resting on a thinned continental crust resulting from the Oligocene to present backarc extension above the north-plunging Hellenic subduction zone (Le Pichon and Angelier, 1979; Le Pichon, 1982; Jolivet et al., 1994a; Gautier et al., 1999). Extensional structures are widely distributed within the Aegean Sea itself and in its vicinity from western Turkey, northern Greece and Bulgaria, continental Greece, Peloponnese and Crete. The Gulf of Corinth separates continental Greece from the Peloponnese. Intense seismicity (Papazachos and Papazachos, 1989; Ambraseys and Jackson, 1990; Papazachos and Kiratzi, 1992) is recorded within the rift and its vicinity. Extension 
started in the Aegean region some 30-35 Ma ago, probably due to an acceleration of slab retreat (Jolivet and Brun, 2008).

Blueschists and eclogite-facies rocks make a significant volume of the Aegean crust (Figure 4). During the construction of the Hellenides they were formed in two main stages, one in the Eocene (the Cycladic Blueschists) (Blake et al., 1981; Bonneau and Kienast, 1982; Wijbrans et al., 1993) and one, more external, in the Oligocene and Early Miocene (the external Phyllite-Quartzite nappe and part of the Plattenkalk nappe in the Peloponnese and Crete) (Seidel et al., 1982; Theye and Seidel, 1991; Jolivet et al., 1996). A very significant part of the exhumation was achieved within the subduction zone before and during the formation of the Aegean Sea (Avigad et al., 1997; Trotet et al., 2001; Jolivet et al., 2003; Ring and Layer, 2003). Kinematic orientations of both exhumation stages are however often very similar in the field (Gautier, 1994) in the Aegean, and deciphering the respective contributions of the two processes is not always straightforward.

\subsection{The Aegean region, the Hellenides and the Corinth Rift}

The Corinth Rift (figure 1) is an active post-orogenic extensional structure set on a previously thickened continental crust that contains HP-LT units exhumed during the Miocene. The Corinth rift strikes $100-110^{\circ} \mathrm{N}$ and runs at a high angle to the Hellenides (figure 3), an alpine stack of nappes developed from the Eocene to the Miocene at the expense of the subducting Apulian continental plate (Aubouin and Dercourt, 1965; Jacobshagen et al., 1978; Bonneau, 1982; 1984; Dercourt et al., 1986). From 5 Ma until the Present plate kinematics has been mostly compatible with the westward extrusion of Anatolia (McKenzie, 1972; 1978; Le Pichon et al., 1995; Armijo et al., 1996; McClusky et al., 2000) along the NAF which ends in the transtensional North Aegean trough (Armijo et al., 1999; 2002; Koukouvelas and Aydin, 2002; Le Pichon et al., 2003). The strike-slip system abuts against the northeastern coast of Greece and is replaced further to the SW by a series of normal faults (Laigle et al., 2000) and grabens, including the Evia and Corinth rifts.

Although most of the motion of the extruded Anatolian block can be modelled as a rigid rotation, the southern part of the Aegean region moves faster southward, inducing extension in the backarc region at a rate of $\sim 1 \mathrm{~cm} / \mathrm{yr}$ (Le Pichon et al., 1995; McClusky et al., 2000). 
The present-day velocity field, as shown by GPS measurements, has been modelled in various ways, either purely kinematically or involving some mechanical considerations (Briole et al., 2000; Flerit et al., 2004; Kreemer and Chamot-Rooke, 2004; Kreemer et al., 2004; Nyst and Thatcher, 2004). Most of the recent Aegean extension is taken up by E-W grabens in western Turkey (Hetzel et al., 1995; Bozkurt and Oberhänsli, 2001; Purvis and Robertson, 2004) and in the Corinth Rift, whereas the more central Cycladic archipelago does not show significant extension nowadays, after a period of intense crustal thinning in the Late Oligocene and Miocene (Gautier and Brun, 1994b; Vanderhaeghe, 2004; Brichau et al., 2007; Jolivet and Brun, 2008). The southern parts of the Peloponnese and Crete are affected by a series of N-Strending active or recent normal faults (figures 1 and 3). Normal faults are clearly perpendicular to the arc in Crete but become more parallel to it in the Peloponnese (LyonCaen et al., 1988; Armijo et al., 1992). This deformation is induced by a component of extension parallel to the external arc according to Armijo et al. (1992)

\subsection{The Corinth Rift: steep faults versus shallow-dipping detachment?}

The age of the first extension in the Gulf of Corinth is poorly constrained but is generally thought to have started recently in the Plio-Quaternary (Keraudren and Sorel, 1987; Ori, 1989; Armijo et al., 1996; Sorel, 2000). The most ancient date corresponds to 3.6 to $4 \mathrm{Ma}$ old syn-rift volcanics (Collier, 1990; Collier et al., 1992) in the eastern part of the rift. Recent datings in the Megara Basin suggest that extension was already active in the vicinity of the Gulf of Corinth in the Pliocene and that the deep part of the rift formed some 2 Ma ago (Leeder et al., 2008). Although very recent dates (120 000 years) have been proposed (Moretti et al., 2003) for the inception of the most recent phase of activity based on the geometry of the fault scarp, recent biostratigraphic studies (Ford et al., 2007; Rohais et al., 2007a; b) of the syn-rift deposits on the southern margin suggest that the oldest deposits date back at least to 1.7 Ma, that an increased subsidence is recorded at 1.0-1.5 Ma and that the recent uplift of the southern margin started at 0.7-0.6 Ma when conglomerate fans suddenly emerged. In all cases, the recent and rapid stage seems to correspond to an acceleration of extension and to a more localised deformation along a few major faults. While Sorel (2000) argues for a single phase with a northward propagation of normal faults, most authors agree that earlier phases 
(one or several) were slower and that deformation was more widely distributed (Armijo et al., 1996).

The Corinth Rift is one of the most typical areas where steep normal faults seem to control the kinematics of extension (Jackson et al., 1982; Roberts, 1996) with one set of faults (the N-dipping one) predominating, giving an asymmetric structure. In line with this asymmetry, north-dipping normal faults of the southern margin seem to have migrated northward during rifting (Goldworthy and Jackson, 2001). A simple model relating the amount of extension and uplift with the motion along one single steep normal fault has been developed in the eastern part of the Gulf of Corinth (Armijo et al., 1996) (Figure 2). This model is mainly based upon the observed crustal-scale flexure of the Xylocastro Fault footwall, documented by mapping of the inner edges of recent uplifted terraces on the southern margin of the gulf near Corinth. The geometry of uplifted marine terraces constrains a long-term elastic flexure model and provides a slip rate of 6 to $11 \mathrm{~mm} / \mathrm{yr}$. In this model, the elevated relief of the northern Peloponnese partly results from the activity of this normal fault. Armijo et al. (1996) further assume that this velocity is representative of the last 1 Ma period. On the other hand, Cornet et al. (2004a), based on drilling of the active steeply-dipping and planar Aigion fault in the west, propose an active slip rate of $\sim 3.5 \mathrm{~mm} / \mathrm{yr}$. Dating of corals in the westernmost part of the Gulf (Houghton et al., 2003) suggests even slower slip rates. The western part of the Gulf, near the junction with the Gulf of Patras, thus seems to show a more limited finite extension (Armijo et al., 1996) despite higher instantaneous GPS rates of extension at present (Briole et al., 2000).

The distribution of earthquakes at depth is in general compatible with an asymmetric model: the main shock hypocentres in the western Gulf are located below the northern shore whereas the main active faults are observed along the southern coast (King et al., 1985; Bernard et al., 1997; Lyon-Caen et al., 2004). This observation led King et al. (1985) to postulate the existence of a shallow-north-dipping detachment at depth into which the main surface faults root. Distributed normal faults are nevertheless also observed in the northern part of the Gulf (McNeill et al., 2005b) and the asymmetry might be less clear during the recent period for the upper crust (Bell et al., 2008). In the same region, two detailed studies of the microseismicity (near Aigion in 1991 and 2001) reveal a clustering of microearthquakes along a shallow north-dipping zone at 5-8 km (Rietbrock et al., 1996; Rigo et al., 1996; 
Lyon-Caen et al., 2004). This zone of microearthquakes is $\sim 2 \mathrm{~km}$ thick and extends laterally over a zone at least $30 \mathrm{~km}$ wide, centered on the town of Aigion. Focal mechanisms of these earthquakes are all extensional and involve one nodal plane parallel to the zone of microseismicity, thus suggesting the presence of an active shallow-dipping shear zone in the vicinity of the brittle-ductile transition (Rigo et al., 1996). Below this zone, no seismicity is recorded and its base thus likely represents the brittle-ductile transition. A tomographic study also revealed the presence of a fluid-rich zone superimposed to the zone of microseismicity (Gautier et al., 2006). In the eastern part of the gulf the cut-off depth of microearthquakes is deeper (10-15 km) and no clear planar structure has been identified (Hatzfeld et al., 2000).

An original model has been proposed by Sorel (2000) for the western part of the gulf (Figure 2). Based on a detailed mapping of the southern shore of the Gulf south of Aigion and Patras, Sorel (2000) proposed the existence of a shallow-north-dipping detachment, active during the Pleistocene and rooting in the microseismicity zone. Steep normal faults root in this detachment and separate narrow tilted blocks and syn-rift tilted sediments sometimes showing rollover structures (Flotté and Sorel, 2001; Flotté et al., 2005). It should be noted here that the geometry of this detachment seems at first glance incompatible with the attested steeply north-dipping faults and the crustal-scale flexure. If this detachment has played a role in the extension across the rift it must have been before the formation of the active Xylokastro and similar faults (see discussion below).

Moretti et al. (2003) challenged the asymmetry of the rift and proposed that the main part of the evolution was more symmetric with north- and south-dipping normal faults, with a recent evolution toward a more asymmetric geometry with the localisation of depocentres near the southern shore, but only in the central and eastern part of the rift. Indeed, while the asymmetry of offshore syn-rift deposits is clear in some sections (Higgs, 1988) more symmetrical patterns prevail on others, with south-dipping faults and northward tilted deposits in the western part of the rift (McNeill et al., 2005b).

Mapping of the southern shore led Ghisetti and Vezzani (2005) to highlight an important difference between the western and eastern sectors. In the west, uplifted PlioPleistocene syn-rift deposits are thin (Aigion sub-basin) and the cut-off of present-day seismicity is shallow, while in the east the Plio-Pleistocene syn-rift deposits (Derveni-Corinth sub basin) are much thicker and the cut-off of seismicity deeper. This difference is attributed 
to the presence of a basement culmination between the two areas in the Zaroukla-Feneos tectonic window (figure 5) where the Phyllite-Quartzite (PQ) nappe crops out below two tectonic units of the Hellenic nappe stack, the Pindos and Gavrovo-Tripolitza nappes (see also figure 3). The difference of penetration of normal faults and seismicity in the western and eastern sectors is compatible with the thickness of syn-rift deposits and is attributed to different depths of the Phyllite-Quartzite nappe acting as a detachment level (Ghisetti and Vezzani, 2005). The role potentially played by a low-viscosity layer (the Phyllite-Quartzite nappe) in localising deformation on a shallow-dipping plane has been advocated by several authors and recently modelled numerically (Le Pourhiet et al., 2004; 2006; Ghisetti and Vezzani, 2005). These numerical experiments show that, depending upon the viscosity contrast between the surrounding rocks and the weak nappe, as well as upon the overall resistance of the crust, normal faults can root at two different levels, the brittle-ductile transition and/or the dipping weak PQ nappe.

\subsection{The Phyllite-Quartzite nappe and the Tyros beds: Cretan detachment vs Zaroukla}

\section{decollement}

In terms of lithology, the Phyllite-Quartzite (PQ) nappe (Creutzburg, 1977; Bonneau, 1984) is contrasting with the rest of the nappe stack of the external Hellenides. Made essentially of metapelites, metaquartzites and metaconglomerates, with minor limestones and some slices of basement (Romano et al., 2004), it is sandwiched between two thick carbonate units, the PlattenKalk (PK) (or Ionian) nappe below and the Gavrovo-Tripolitza (GT) nappe above (Figure 5). It is recognized from Crete to the Peloponnese, yet its thickness is highly variable. It can be more than one km thick in western Crete and totally absent in parts of central Crete.

Unlike the GT nappe, the PQ nappe contains high-pressure and low-temperature (HPLT) metamorphic rocks. The age of metamorphism is dated from the Late Oligocene to the Early Miocene. The underlying PK nappe is metamorphosed in Crete but not in the 
Peloponnese (Seidel et al., 1982; Theye and Seidel, 1991; 1993; Theye et al., 1992; Jolivet et al., 1996; Thomson et al., 1998; Trotet, 2000; Zulauf et al., 2002).

The PQ nappe is partly similar in lithology to Triassic pelitic and volcanic rocks that make the base of the GT nappe (Tyros Beds) and the confusion is possible in the field. The Tyros beds are however devoid of any HP-LT metamorphic imprint. There is thus a strong metamorphic gap between the Tyros beds and the PQ nappe. This gap is classically interpreted as the result of the activity of a shallow-dipping detachment, the Cretan detachment, that has exhumed the high pressure rocks during the Early and Middle Miocene and ultimately controlled the formation of early late Miocene basins in its hangingwall (Fassoulas et al., 1994; Jolivet et al., 1994b; 1996; Kilias et al., 1994; Ring et al., 2001; van Hinsbergen and Meulenkamp, 2006; Seidel et al., 2007).

The Cretan detachment is characterized by a localisation of a large-scale shear zone at the top of the PQ nappe in Crete (Jolivet et al., 1996). This shear zone evolves in time from ductile to brittle during exhumation from the depth of the blueschist facies and the shear sense is consistently top-to-the-north. In the Peloponnese the retrograde deformation is also present, but the asymmetry is less clear with both top-to-the-west and top-to-the-east indicators on either sides of the Taygetos range (Xypolias and Doutsos, 2000; Jolivet et al., Tectonophysics, in revision). Despite a more complex internal structure of the PQ nappe the pressure gap with the overlying Tyros Beds (and GT nappe) is also present and a series of detachments have exhumed HP-LT units. Most of this exhumation-related deformation took place within the subduction channel or the accretionary wedge before post-orogenic extension started in Crete or the Peloponnese. Part of this detachment system has been reactivated in recent periods (Middle Miocene to early Pliocene) as the East Peloponnesus Detachment (Papanikolaou and Royden, 2007) and the Itea-Amfissa Detachment (Papanikolaou et al., 2009).

The PQ nappe is also recognized in the Zaroukla-Feneos window (figures 1 and 5) south of the Corinth Rift where Sorel (2000), Flotté and Sorel (2001) and Flotté et al. (2005) have first suggested that the base of the GT nappe acted as a shallow-dipping detachment during the formation of the Corinth Rift (hereafter called the Zaroukla decollement). Their proposition is based upon the direct observation of a shallow north-dipping fault on the northern slope of Mount Chelmos and its lateral continuation east and west, the construction 
of a series of balanced cross-sections and the northward migration of the activity of normal faults through time.

\section{Detachments associated with the Corinth rift}

\subsection{Zaroukla decollement vs Cretan detachment}

In order to precise the geometry of the contact between the Tyros Beds above and the PQ nappe below we have mapped the Zaroukla-Feneos window (figure 5). The Cretan detachment is located at the interface where a pressure gap is also documented: a maximum pressure of $10 \mathrm{kbar}$ is recorded in the PQ nappe while the Tyros beds underwent pressure conditions below 5-6 kbar (Jolivet et al., Tectonophysics, in revision). The deformation within the PQ nappe is characterized by a shallow-dipping foliation folded in a broad antiform with a steeper southern limb. A stretching lineation, now trending NE-SW, is observed throughout the window. It is associated with a majority of top-to-the-NE kinematic indicators but also a significant number of top-to-the-SW ones in the southern limb (see also Xypolias and Doutsos, (2000). The Tyros Beds above do not show this ductile deformation. The contact between the PQ nappe and the Tyros beds thus accommodated a significant displacement that resulted in the juxtaposition of two units with different $P$ - $T$ evolutions and different deformation histories. The downward increase of pressure across the contact is in favor of an extensional movement or exhumation-related detachment tectonics as in the southern Peloponnese or in Crete. Through an analogy with Crete and the Southern Peloponnese, we assume that this exhumation took place in the Early and Middle Miocene. The recent dating of Middle Miocene sediments in the hangingwall of the Itea-Amfissa Detachment (Papanikolaou et al., 2009) north of the Corinth Rift is in line with this conclusion.

The detachment mapped by Sorel (2000) lies above the Cretan detachment. A thick zone of cataclasites can be observed at the base of the GT carbonates along the Kratis valley (figure 5). It can be followed along the road along several hundreds of meters and is visible also on the left bank of the river. The carbonates are intensely brecciated in a several tens of meters thick zone. A number of shallow-dipping normal faults can be observed within the 
breccia. They all dip northward and indicate an almost N-S direction of extension, oblique on the stretching lineation observed below the Cretan detachment, but parallel to the present-day extension direction across the Corinth Rift. We interpret it as a recent feature related to the Zaroukla decollement. Several faults located further south, such as the Agridi fault root onto the decollement that is, however, clearly cut by one or several steeper faults, such as the Tsivlos Fault that limits the Tsivlos syn-rift basin to the south (figure 5). The geometry of the basin with fan-shaped deposits suggests that the fault root into a rather shallow decollement (Flotté and Sorel, 2001) that could be the reactivation of the Cretan detachment, that is the nearest weak level.

Finally, the geology of the Zaroukla-Feneos window shows that two important discontinuities of the nappe stack could play a role during extension and provides the following chronology: 1) The Cretan detachment, which exhumed the HP-LT PQ nappe during the Late Oligocene and Early Miocene, might have been partly reworked during the recent period, 2) The Zaroukla decollement, located at the base of the GT carbonates and above the Tyros Beds, shows kinematics compatible with the direction of extension during the formation of the Corinth rift, 3) The Zaroukla decollement is cut by steep faults that may root in the deeper Cretan detachment, located deeper between the Tyros beds and the underlying PQ nappe. From Crete to the southern limit of the Corinth rift, the Hellenic crust has thus been structured by a succession of tectonic processes: nappe stacking, syn-orogenic exhumation of the PQ nappe in the subduction channel and post-orogenic extension. Whatever the amount of exhumation attributed to syn-orogenic exhumation, the role of the Cretan detachment at the top of the PQ nappe was major. This detachment, as well as other shallow-dipping contacts in the nappe stack, are major crustal discontinuities that could have played the role of a decollement at crustal scale. This is reinforced by the weak rheology of the PQ nappe (mica-rich metapelites in majority and a highly heterogeneous material, thus of probable low overall strength) compared with the overlying (GT) and underlying (PK) nappes (more homogeneous and mainly carbonates). In a recent paper Rahl et al. (Rahl et al., 2005), based on maximum temperature estimates in carbonaceous material on both sides of the Cretan detachment concluded to a limited displacement because of a small temperature difference across the main movement zone. However, as argued in Jolivet et al. (1996) and discussed in Jolivet et al. (Tectonophysics, in revision) metamorphic parageneses clearly 
show a significant pressure gap between the hangingwall and the footwall, and only pressure can be used to estimate the vertical component of offset.

\subsection{A crustal-scale cross-section of the Corinth rift}

Figures 6 and 7 present a synthetic cross-section through the Corinth Rift. Several available data sets and our own observations were used to construct this interpretative section. We use the work of Flotté and Sorel (2001) and Flotté et al. (2005) along the Kratis river as a starting point for the onshore section. We build a new balanced section with the assumption that blocks between faults are entirely rigid, except in the lower part within the Tyros beds. In Flotté and Sorel (2001) and Flotté et al. (2005) the depth of the detachment is constrained by the geometry of the pre-rift nappe contacts used as originally horizontal markers and we use the same assumption here. This assumption is reasonable considering the attitude of the contact between the Pindos and GT nappe further south in the Peloponnese where the effect of the Corinth rifting is not present. The relatively shallow depth of the detachment is compatible with the size of tilted blocks (4-5 $\mathrm{km}$ at most). We introduce the two discontinuities described above, one (Zaroukla decollement) between the Tyros beds and the GT nappe and one (Cretan detachment) between the Tyros beds and the PQ nappe. The Zaroukla decollement is cut by at least one large north-dipping normal fault rooting in the Cretan detachment (figure 6B).

Further north, the main active faults (Xylokastro, Helike) along the southern shore of the gulf have induced a significant uplift of the rift shoulder (Armijo et al., 1996). The wavelength of the elastic flexure evidenced by the deformation of terraces in the east implies a deep-seated fault that cuts the entire brittle part of the crust (Armijo et al., 1996). This observation implies that these steeply dipping faults cut through the more superficial detachments and were thus active at a more recent stage. This is compatible with seismological observations suggesting that these faults are planar down to the brittle-ductile transition (Jackson et al., 1982; Jackson and White, 1989), with the results of drilling through the Aigion Fault (Cornet et al., 2004a) and with the timing of syn-rift deposits on the southern shore (Rohais et al., 2007a; b).

Offshore structures are constrained by 1) several seismic profiles that show either the most recent deposits with a clear half-graben geometry compatible with the presence of major 
faults on the southern shore (Higgs, 1988) or deeper structures showing a more distributed extension with north- and south-dipping faults, but still a clear asymmetry in the recent deposits with a depocentre near the southern shore (Clément, 2000; Sachpazi et al., 2003), 2) the southward migration of the depocentre through time (Moretti et al., 2003), 3) seismic profiles imaging deeper portions of the crust and advocating for the presence of a shallow north-dipping fault (Bernard et al., 1997), 4) a seismogenic shallow-dipping zone associated with low seismic velocities and probable intense fluid circulations (Gautier et al., 2006) (figure 6) .

We thus consider three main shear zones in our section, from top to base: the Zaroukla decollement, the Cretan detachment (reactivated as a decollement) and a thick shallowdipping shear zone located above and within the brittle-ductile transition. This deep decollement is envisaged as a shallow-dipping thick zone of deformation including some cataclastic flow at the top, leading to the observed microseismicity and ductile flow at the base. All three shallow-dipping shear zones, connected by steeply dipping ramps, constitute a crustal-scale detachment.

The question then is how the Cretan detachment continues north of the Helike and Aigion faults below the gulf. A possible connection with the Itea-Amfissa detachment (Papanikolaou et al., 2009) north of the Gulf should also be envisaged but it has not been studied in the framework of this paper. The total amount of offset along the Helike fault system is unknown as some more faults might be hidden below the syn-rift sediments offshore. The depth of the contact between the GT nappe and the PQ nappe north of the Aigion fault is thus difficult to constrain. Armijo et al. (1996) estimate the total offset along the Xylokastro fault to $\sim 7 \mathrm{~km}$ based on modelling of the observed flexure, using a long-term elasticity parameter. They also suggest that the cumulative offset tends to decrease westward. The Helike fault has a geometry quite similar to the Xylokastro fault but such a large displacement is excluded by the result of drilling across the Aigion fault that shows the presence of the Pindos-like lithologies at a depth of $\sim 400 \mathrm{~m}$ only, in the hangingwall of the fault (Cornet et al., 2004b). The geometry of syn-rift sediments shown on the cross-section of figure 6 is based upon the analysis of Flotté and Sorel (2001) but, according to the authors themselves, this part of the section is poorly constrained. Nevertheless, the total amount of displacement between the footwall of the Helike Fault and the hanging-wall of the Aigion 
Fault cannot be more than 2-4 km, depending upon the geometry of the syn-rift deposits between the two faults. This value is similar to some estimate of subsidence of the hangingwall of the Helike Fault (McNeill and Collier, 2004). If a total larger displacement has to be found it must be mostly accommodated offshore but with a total amount smaller than to the east, as attested by the cumulated sediment thickness (Clément et al., 2004) that encompasses a longer time period than the activity of the Helike Fault. Restoring the crosssection (figure 7) allows to estimate the amount of extension. We find $8 \mathrm{~km}$ for the onshore section, that is twice smaller than in Flotté and Sorel (2001) on the same section. This difference mainly arises from our choice of totally rigid blocks between faults. In addition, the offshore sedimentary basin and its fault pattern have been restored in a way similar to Sachpazi et al. (2003). The total extension then becomes $13 \mathrm{~km}$ across the entire rift. If extension has started some $1 \mathrm{Ma}$ ago this leads to an average rate of $13 \mathrm{~mm} / \mathrm{yr}$ grossly compatible with the $1.5 \mathrm{~cm} / \mathrm{yr}$ measured rate (Briole et al., 2000). Recent studies dealing with offshore recent steep faults have estimated extension rates in the western part of the Gulf, 8$16 \mathrm{~mm} / \mathrm{yr}$ (McNeill et al., 2005b) or 5-14 mm/yr (Bell et al., 2008). These rates being in the range of geodetically measured extension velocities those authors conclude that a shallowdipping detachment below is unnecessary. However we have seen that if the shallow-dipping Zaroukla decollement and Cretan detachments have played a role in the formation of the Gulf of Corinth, it had to be before the formation of the recent steep faults, and the extension rate at this period is unknown.

We have considered throughout this paper a general asymmetric structure for the Corinth Rift. Although we have assigned to the north-dipping recent faults on the southern margin a throw twice smaller compared to Armijo et al. (1996), as suggested by McNeill and Collier (McNeill and Collier, 2004), we agree with Armijo et al. on the predominance of north-dipping faults. The main reasons are that (1) the main active faults are located along the southern margin and that the maximum syn-rift sediment thickness is found in the southern half of the Gulf even when important south dipping faults such as the East Channel Fault have been recognized on seismic reflection data(Bell et al., 2009), (2) syn-rift sediments have been uplifted only on the southern margin while the northern margin has been either steady or slowly subsiding, showing an asymmetry on the long term. The degree of asymmetry and the 
throw of the north-dipping faults seem to decrease and south-dipping faults become more significant westward.

4. Comparison with the northern Cycladic metamorphic core complexes and detachments

The cross-section of figures 6 and 7 shows that available data are compatible with a series of three movement zones reaching deeper portions of the crust northward, making altogether a crustal-scale detachment. The two upper decollements are due to the presence of shallow-dipping low-strength levels in the crust before the formation of the rift and correspond to inherited structures (stratigraphic contacts, nappe contacts and/or extensional shear zones). The lower shear zone using the brittle-ductile transition can be controlled by the effects of fluids on rock strength (Gueydan et al., 2003; 2004; Gautier et al., 2006). The presence of a north-dipping detachment partly controlling the deformation in the Corinth rift is compatible with the overall crustal structure that suggests a shallower Moho north of the gulf and not immediately beneath it (Tiberi et al., 2001).

As discussed by Ghisetti and Vezzani (2002) the geometry of normal faults and syn-rift basins are different east and west of the Zaroukla culmination with a deeper root zone for normal faults in the east. The Zaroukla decollement pierces the surface right above the culmination. It is thus possible that a pre-existing dome, formed during the Miocene phase of exhumation, has localized the detachment zone on its eastern flank during the recent rifting episode.

Deeper structures and details of the present-day deformation regime below the active rift can only be guessed, but a comparison with the nearby Cyclades can bring interesting insights if our assumption of a continuum of extension holds.

In the Cyclades two main types of detachments are exposed. The first type is exposed along the southern coast of Tinos or on Syros island where it puts in direct contact well preserved blueschists and eclogites in the lower unit and an upper unit without any Eocene HP metamorphic imprint (Jolivet et al., 2004). Those detachments were active in the Eocene 
in the upper part of the subduction channel (Trotet et al., 2001; Jolivet et al., 2003). The second type of detachment is found on many islands, such as Tinos, Andros, Mykonos, Paros or Naxos. They formed some time later from the late Oligocene to the Middle Miocene and are responsible for crustal thinning and formation of the extensional metamorphic domes (Gautier and Brun, 1994a; b). Tinos shows both sets of detachments, the early one on the southwestern coast, the later one on the northeast and northern coast.

We focus our comparison on the northern Cycladic islands of Andros, Tinos and Mykonos that are aligned along a NW-SE axis prolonging the crustal block of Evia limited by major normal faults (figure 3). A NW to SE gradient of finite extension has exhumed deeper portions of the crust during the Miocene (Avigad and Garfunkel, 1989; Jolivet et al., 1994a; Jolivet and Patriat, 1999). Recent and active normal faults dip steeply to the northeast at the latitude of Mt Olympos, and shallow NE-dipping faults have been imaged northeast of Evia (Laigle et al., 2000). In Andros, Tinos and Mykonos a shallow NE-dipping detachment is observed. A crustal-scale shear zone has been described in the footwall of the detachment (Faure et al., 1991; Gautier and Brun, 1994a; Jolivet et al., 2004; Mehl et al., 2005; 2007) with a conspicuous NE-trending stretching lineation, top-to-the-NE shear sense, and a progressive localisation of shear during the transition from ductile (greenschist facies conditions) to brittle regime. Steeply- and shallowly-dipping small-scale normal faults are observed in the footwall and the analysis of the relationships between veins and faults indicates that some of the normal faults were originally shallow-dipping (Mehl et al., 2005). Two main mechanisms progressively localise the deformation along a few major extensional shear zones (Jolivet et al., 2004; Mehl et al., 2005; 2007). The initial localising event is boudinage that is observed at all scales. During the transition from ductile to brittle, extensional shear zones, and then normal faults tend to localise within the necks between boudins. This is seen at the scale of the outcrop and the evolution seen on Andros island suggests that it works also at the scale of the crust. Some of the shear zones and faults were then invaded by fluids coming from the surface (Famin et al., 2004a; b; 2005)., allowing (1) the formation of weak metamorphic phases and (2) a weakening of the rock material, thus promoting further localisation. Deeper in the crust the deformation was less localised at higher temperature, and the cases of Mykonos and Naxos show clear evidence for intense partial melting (Jansen and Schuilling, 1976; Gautier et al., 1993; Vanderhaeghe, 2004; 
Duchêne et al., 2006). Within the upper crust much of the displacement is likely accommodated by cataclastic flow in a zone of finite thickness and not on a simple fault plane, only the last increments of motion being truly brittle (Mehl et al., 2005; 2007).

Figure 8 illustrates some of the characteristic features of the extensional deformation and indicates where similar structures can be expected below the Corinth Rift. The detachment itself is illustrated by the three examples of Andros (Mehl et al., 2007), Tinos (Jolivet and Patriat, 1999; Jolivet et al., 2004; Mehl et al., 2005) and Mykonos (Lecomte et al., submitted).

Along the northeastern coast of Andros the detachment is exposed between an upper plate made of greenschists and serpentinite cut by a set of NE-dipping normal faults that root on the main shallow-dipping detachment (figure 8c). The lower plate is made of the Cycladic Blueschists, highly retrograded in the greenschists facies during exhumation and later extension. A level of cataclasites, formed at the expense partly of the serpentinite and partly of the underlying micaschists is observed below the main fault. In the core complex itself the Oligo-Miocene deformation is characterized by an intense foliation boudinage that is observed at all scales. Boudins shape evolve from symmetrical in the southwestern part of the island (Figure 8E) to asymmetrical in the northeastern part (Figure 8F), when getting close to the detachment. Numerous shallow and steeply dipping shear zones and faults are associated to the ductile then brittle expression of this boudinage. Some of these shear zones and faults can be much larger in size. They are observed close to the detachment and they can be followed along several hundreds of meters. These characteristics are those expected in the vicinity of a large-scale shear zone with a shallow-dip working during exhumation across the ductile-brittle transition.

On Tinos island, like on Andros, the detachment is located between an upper plate made of greenschists, metagabbros and serpentinite and a lower plate made of the Cycladic Blueschists. The upper plate is cut by NE-dipping steep faults (Figure 9) and steep tension gashes (figure 8D) and some ductile deformation is observed near its base on the islet of Planitis along the NE coast of Tinos. The lower plate shows a strong strain gradient and greenschist retrogression from SW to NE when approaching the detachment. Boudinage and shallow-dipping shear zones are more and more intense toward the NE and an evolution from ductile to brittle is observed with the persistence of the same direction of stretching and top- 
to-the-NE shear sense through time. Ductile shear bands are often reworked as brittle faults. The detachment itself is a clear cut shallow-dipping fault $\left(10^{\circ}\right)$ associated to a zone of talcrich cataclasites of variable thickness and a set of steep and shallow-dipping faults of variable size (figures 8D and 10). Figure 10 shows the foliation in Kolympithra on the NE coast of Tinos, reworked by shallow-dipping faults and penetrated by fluids within numerous veins that increase in density upward. It has been shown that the fluids are of meteoric origin (Famin et al., 2004b) within the shear zone. Deeper parts of the core complex show only metamorphic fluids of local origin.

On Mykonos island, the shallow-dipping detachment is divided in two branches (Lecomte et al. submitted). The lower branch is ductile and it separates an upper plate made of greenschist metabasites from a granite dated from the Late Miocene (Sanchez-Gomez et al., 2002; Brichau et al., 2008). The granite intrudes the upper plate and a ductile deformation localised along the contact. This deformation is observed in the whole pluton (Faure et al., 1991) and its intensity increases when approaching the contact. The upper branch of the detachment separates the metabasites from a coarse sedimentary breccia at the base and syntectonic sandstones and conglomerates that rework the underlying granite at the top (figure 8B). The sediments are cut by steep faults rooting on the shallow-dipping $\left(12-15^{\circ}\right)$ detachement. The dip of normal faults is compatible with the regional top-to-the-NE shear sense seen in the granite and along the ductile branch of the detachment. A zone of cataclasite of variable thickness (2-10 meters) is developed at the expense of the metabasites.

On figure 8 we have extended the cross-section of figure 6 at depth using a comparison with the Cyclades based on the following observations: (1) the general sense of asymmetry is similar in the case of Corinth and of the Cyclades, top-to-the-north shear sense below and close or within the brittle-ductile transition, (2) the depth of the shallow-dipping seismogenic zone is just above or partly within the depth where greenschist facies parageneses are expected, and (3) the shear zone active below the rift is probably invaded by fluids exactly as the shear zones in the Cyclades.

Pressure conditions within the seismogenic zone can be directly deduced from the depth and are compatible with the greenschist facies. Temperature estimates can be inferred from heat flux constraints. A low gradient of the order of $23 \% / \mathrm{km}$ was obtained in the Aigion well above the Aigion fault and the temperature was constant below (Cornet et al., 2004b). This 
suggests that a strong advection is present within the karst and that the temperature gradient above the fault might not be representative of the heat flow at crustal scale. The depth of cutoff of seismicity is not unusual for a continental crust in equilibrium. If it corresponds to the brittle-ductile transition of wet-quartz the ductile zone begins immediately below at temperatures above $350^{\circ} \mathrm{C}$ compatible with greenschist facies conditions. Besides, helium isotopic ratios show that no mantle-derived fluids have reached the surface in the Corinth Rift (Cornet et al., 2004b; Pik and Marty, 2008) and no recent volcanic rocks are present in this part of the rift.

We thus propose that what is seen below Corinth in the present-day configuration is in a first approach similar to what has been exhumed through a long process of extension and exhumation during the Miocene in the Cyclades. We thus propose a tentative complete crosssectional model of an extending crust. The faults, steep or shallow-dipping seen in the Cyclades in the vicinity of detachments and the observed cataclasites could represent good analogues of the microseismicity recorded below the Gulf of Corinth. The invasion of the shear zones and cataclasites by surface-derived fluids could be good analogues of the fluids suggested by tomographic images below Corinth within the zone of microseismicity. The upper part of the Corinth detachment could find an analogue in the upper branch of the Mykonos detachment where sediments are still soft when the faults are active.

\section{A model of evolution for the Corinth Rift}

The model we propose for the Corinth Rift shows an asymmetric structure at the scale of the crust with several north-dipping movement zones in low-strength levels. The deep structure is based upon the comparison with the nearby Cycladic metamorphic core complexes. It is not yet clear whether the deepest of these movement zones is the direct consequence of the presence of the PQ nappe at depth or an intrinsic consequence of the behaviour of the brittle-ductile transition where fluids accumulate with time and help to localise shear zones as recorded in the Cyclades.

Let us first recall that this evolution rests on the following major constraints: several recent studies on the southern margin of the rift document a northward migration of normal faults and depocentres (Sorel, 2000; Flotté and Sorel, 2001; Goldworthy and Jackson, 2001; 
Flotté et al., 2005). A strong regional uplift is associated with the development of the recent coastal faults (Armijo et al., 1996). Older faults did not induce such a large regional uplift confirming that they do not cut through the entire elastic crust and are thus quite superficial structures. A recent study (Rohais et al., 2007a; b) shows a progressive northward extinction of normal faults during the period 1.5-0.7 Ma before the localisation of deformation along the major active faults. A significant change in the behaviour of normal faults thus occurred some 0.7 Ma ago. The recent faults seem to affect a deeper portion of the crust than older ones, and they affect the entire upper elastic crust. The overall amount of extension is limited but an acceleration occurred 0.7 Ma ago. Before this abrupt change in deformation and syn-rift deposits, extension was distributed over a wider region. The difference between the western and eastern part of the Gulf could be due to the pre-rift structure of the Hellenic chain before the Pliocene as proposed by Ghisetti and Vezzani (2005). Thicker syn-rift deposits in the east could be the result of a deeper decollement in the east and normal faults reaching deeper portions of the crust. Furthermore, the larger depth of the decollement in the east could explain that it is seismologically silent, as it would be below the brittle-ductile transition. An alternative, or additional, explanation is that finite extension is larger in the east as suggested by the overall width of the rift and the total synrift deposit thickness on the southern margin, and that the eastern section represents a more advanced stage with a stronger overall subsidence before the main active faults localised on the southern coast. This second suggestion is similar to the proto-Corinth Rift that would have been reactivated by the recent extension (Armijo et al., 1996).

The first stage in the recontruction (Figure 11) is set after the end of synorogenic exhumation, before inception of crustal-scale post-orogenic extension. HP-LT units such as the PQ nappe have been exhumed within the subduction channel, below a syn-orogenic detachment that forms the roof of the channel. This detachment introduces a planar heterogeneity in the crust. Depending of the exact geometry of the subduction channel a dome could already exist at this stage. It must be also noted at this stage that the existence of the east Peloponnesus Detachment (Papanikolaou and Royden, 2007) related to a Middle Miocene to early Pliocene post-orogenic extension also introduces a shallow-dipping heterogeneity. At around 1.7 Ma or earlier (3 Ma ?) post-orogenic extension starts in the proto-Corinth rift and extension is localised along the pre-existing shallow-dipping 
discontinuities such as the Zaroukla decollement, the Cretan detachment or the brittle-ductile transition. The three discontinuities may be active at the same time and normal faults root on one or the other (Le Pourhiet et al., 2004). In the first period (before $0.7 \mathrm{Ma}$ ) extension is distributed on a rather wide region above the detachment. A set of north-dipping normal faults accommodates the northward motion of the hangingwall and small syn-rift basins form. Normal faults progressively cease their activity starting from the south during localisation of the deformation until a large normal fault reaches directly the lowermost shear zone, the brittle-ductile transition. At this stage (from $0.7 \mathrm{Ma}$ onward) the entire elastic upper crust is broken and a large elastic rebound is recorded. This could be due to a higher strain rate due to the acceleration of extension some $0.7 \mathrm{Ma}$ leading to a stiffer rheology and thus to brittle faults reaching deeper portions of the crust. The future evolution is either the continuation of extension on the same large normal faults with little finite extension or an evolution toward a metamorphic core complex and a large finite extension if the main shear zone at the brittleductile transition remains active and is not cut by the major normal faults.

Although resolution in time is not sufficient to say whether the various Cycladic domes formed contemporaneously or one after the other, the main difference between the Gulf of Corinth and the Cycladic core complexes could be a more important localisation of deformation on a single structure in Corinth; most authors considering indeed that the extensional regime has changed between the distributed Cycladic extension and the more localised extension in the Corinth Rift. As discussed above, this might be due to a progressive localisation process that started some $5 \mathrm{Ma}$ ago, at the same time as the North Anatolian Fault migrated in the Aegean domain. Whatever the causes of this migration, it has localised deformation at its tip between the North Aegean Trough and the Kephalonia Fault. An additional difference is the fact that the shallow-dipping surfaces have been cut in the recent period by steep faults and that a core complex has not formed and may never form south of the Gulf. Intuitively, this will all depend upon the stability of these faults through time. If extension keeps going on the same faults the detachment will have definitely ended its activity. If on the contrary these faults are only transient features one may expect a new period of exhumation by the detachment or its future equivalents.

\section{Conclusions}


We have explored in this paper a comparison between the active Corinth Rift and the Oligo-Miocene metamorphic core complexes of the nearby Cyclades. Similarities appear in terms of kinematics, geometry and P-T-fluids conditions. The role possibly played by the Phyllite-Quartzite nappe, a low strength lithology in the Hellenic crust, in the extension process of the Corinth Rift has been discussed. Structural and metamorphic data on the PQ nappe from Crete to the Peloponnese show that a significant pressure-gap exists between the PQ nappe and the overlying tectonic unit, the Gavrovo-Tripolitza nappe, including its base, the Tyros Beds. The pressure gap is best interpreted as a detachment, further attested by the localisation of retrograde deformation along a shear zone at the top of the PQ nappe. The comparison with the Cyclades where post-orogenic detachments have been described suggest that the Cyclades can provide good analogues of the deformation active below the Gulf of Corinth at the depth of the brittle-ductile transition. If our scenario holds, the Aegean region would be a well-suited region to study both active extension with its seismological and superficial geological features, and exhumed deeper extensional strain with its ductile deformation, $P$ and $T$ conditions and the fluids involved in the localisation process.

The proposed cross-section of the Corinth Rift at the scale of the crust and its evolution through time fit a number of first-order observations: the general asymmetry of the Corinth rift on a time scale of at least $1.5 \mathrm{Ma}$, the presence of a seismogenic shallow-dipping zone and a fluid-rich layer near the brittle-ductile transition, the northward migration of faults on the southern margin, the transition from a distributed extension and shallow faults to a more localised one with steep and deep faults some 0.7 Mrs ago through progressive localisation. A question however remains: is the quite abrupt and recent localisation of deformation on the main presently active faults an intrinsic feature of the localisation process, or does it imply a change in the boundary conditions such as a velocity increase?

Aknowledgments: The authors wish to thank those colleagues who helped them during the preparation of this paper through discussion in the lab and in the field : Bertrand Meyer, Laetitia Le Pourhiet, Rolando Armijo and Robin Lacassin, as well as Hélène Lyon-Caen who kindly provided us with the microearthquakes data file. Thanks are also due to Mary Ford, Douwe van Hinsbergen and anonymous reviewers who provided constructive comments on a earlier versions of this paper. This paper is a contribution of the ANR EGEO project. 


\section{References}

Abers, G.A., 1991. Possible seismogenic shallow-dipping normal faults in the Woodlarkd'Entrecasteaux extensional province, Papua New Guinea. Geology, 19: 1205-1210.

Abers, G.A., Mutter, C.Z. and Fang, J., 1997. Earthquakes and normal faults in the Woodlarkd'Entrecasteaux rift system, Papua New Guinea. J. Geophys. Res., 102: 15301-15317.

Ambraseys, N.N. and Jackson, J.A., 1990. Seismicity and associated strain of central Greece between 1890 and 1988. Geophys. J. Int., 101: 663-708.

Armijo, R., Lyon-Caen, H. and Papanikolaou., D., 1992. East-West extension and Holocene normal fault scarps in the Hellenic arc. Geology, 20: 491-494.

Armijo, R., Meyer, B., Hubert, A. and Barka, A., 1999. Westward propagation of the north Anatolian into the northern Aegean: timing and kinematics. Geology, 27(3): 267-270.

Armijo, R., Meyer, B., King, G.C.P., Rigo, A. and Papanastassiou, D., 1996. Quaternary evolution of the Corinth Rift and its implications for the Late Cenozoic evolution of the Aegean. Geophys. J. Int., 126: 11-53.

Armijo, R., Meyer, B., Navarro, S., King, G. and Barka, A., 2002. Asymmetric slip partitionning in the Marmara Sea pull-apart: a clue to propagation processes of the North Anatolian Fault. Terra Nova, 14(2): 80-84.

Aubouin, J. and Dercourt, J., 1965. Sur la géologie de l'Egée: regard sur la Crète (Grèce). Bull. Geol. Soc. France, 7(7): 787-821.

Avigad, A., Garfunkel, Z., Jolivet, L. and Azañón, J.M., 1997. Back-arc extension and denudation of Mediterranean eclogites. Tectonics, 16(6): 924- 941.

Avigad, D. and Garfunkel, Z., 1989. Low-angle faults above and below a blueschist belt: Tinos Island, Cyclades, Greece. Terra Nova, 1: 182-187.

Axen, G.J., Fletcher, J.M., Cowgill, E., Murphy, M., Kapp, P., MacMillan, I., RamosVelasquez, E. and Aranda-Gomez, J., 1999. Range-front fault scarps of the Sierra El Mayor, Baja California: forme above an active low-angle normal fault ? Geology, 27(3): 247-250.

Bell, R.E., McNeill, L.C., Bull, J.M. and Henstock, T.J., 2008. Evolution of the offshore western Gulf of Corinth. GSA Bulletin, 120(1/2): 156-178; doi: 10.1130/B26212.1. 
Bell, R.E., McNeill, L.C., Bull, J.M., Henstock, T.J., Collier, R.E.L. and Leeder, M.R., 2009. Fault architecture, basin structure and evolution of the Gulf of Corinth Rift, central Greece. Basin Research, doi: 10.1111/j.1365-2117.2009.00401.x.

Bernard, P., Briole, P., Meyer, B., Lyon-Caen, H., Gomez-Gonzalez, J.M., Tiberi, C., Berge, C., Cattin, R., Hatzfeld, D., Lachet, C., Lebrun, B., Deschamp, A., Courboulex, F., Larroque, C., Rigo, A., Massonet, D., Papadimitriou, P., Kassaras, J., Diagourtas, D., Makropoulos, K. and Veis, G., 1997. The Ms=6.2, june 15, 1995 Aigion earthquake(Greece): Evidence for low angle normal faulting in the Corinth rift. Journal of Seismology, 1: 131-150.

Bernard, P., Lyon-Caen, H., Briole, P., Deschamps, A., Boudin, F., Makropoulos, K., Papadimitriou, P., Lemeille, F., Patau, G., Billiris, H., Paradissis, D., Papazissi, K., Castarède, H., Charade, O., Nercessian, A., Avallone, A., Pacchiani, F., Zahradnik, J., Sacks, S. and Linde, A., 2006. Seismicity, deformation and seismic hazard in the western rift of Corinth: New insights from the Corinth Rift Laboratory (CRL). Tectonophysics 426: 7-30.

Billiris, H., Paradisis, D., Veis, G., England, P., Featherstone, W., Parsons, B., Cross, P., Rands, P., Rayson, M., Sellers, P., Ashkenazi, V., Davison, M., Jackson, J. and Ambraseys, N., 1991. Geodetic determination of tectonic deformation in central Greece from 1900 to 1988. Nature, 350: 124-129.

Blake, M.C., Bonneau, M., Geyssant, J., Kienast, J.R., Lepvrier, C., Maluski, H. and Papanikolaou, D., 1981. A geological reconnaissance of the Cyclacic blueschist belt, Greece. Bull. geol. Soc. Amer., 92: 247-254.

Bonneau, M., 1982. Evolution géodynamique de l'arc égéen depuis le Jurassique Supérieur jusqu'au Miocène. Bull. Soc. Géol. Fr., 7: 229-242.

Bonneau, M., 1984. Correlation of the Hellenic nappes in the south-east Aegean and their tectonic reconstruction, in The Geological Evolution of the Eastern Mediterranean. In: J.E. Dixon and A.H.F. Robertson (Editors). Special Publication of the Geological Society of London. Blackwell Scientific Publications, Oxford, pp. 517-527.

Bonneau, M. and Kienast, J.R., 1982. Subduction, collision et schistes bleus: exemple de l'Egée, Grèce. Bull. Soc. géol. France, 7: 785-791. 
Bozkurt, E. and Oberhänsli, R., 2001. Menderes Massif (Western Turkey): structural, metamorphic and magmatic evolution - a synthesis. Int. J. Earth Sciences, 89: 679708.

Brichau, S., Ring, U., Carter, A., Bolhar, R., Monié, P., Stockli, D. and Brunel, M., 2008. Timing, slip rate, displacement and cooling history of the Mykonos detachment footwall, Cyclades, Greece, and implications for the opening of the Aegean Sea basin. J. Geol. Soc. Londonc, 165: 263-277.

Brichau, S., Ring, U., Carter, A., Monie, P., Bolhar, R., Stockli, D. and Brunel, M., 2007. Extensional faulting on Tinos Island, Aegean Sea, Greece: How many detachments? Tectonics, 26(TC4009, doi:10.1029/2006TC001969).

Briole, P., Rigo, A., Lyon-Caen, H., Ruegg, J.C., Papazissi, K., Mitsataki, C., Badolimou, A., Veis, G., Hatzfeld, D. and Deschamps, A., 2000. Active deformation of the Corinth rift, Greece: results from repeated Global Positionning System surveys between 1990 and 1995. J. Geophys. Res., 105: 25605-25626.

Brun, J.P. and Choukroune, P., 1983. Normal faulting, block tilting and décollement in a stretched crust. Tectonics, 2(4): 345-356.

Brun, J.P., Gutscher, M.A. and teams, D.-E., 1992. Deep crustal structure of the Rhine Graben from DEKORP-ECORS seismic reflection data: a summary. Tectonophysics, 208: 139-147.

Burchfiel, B.C., Hodges, K.V. and Royden, L.H., 1987. Geology of Panamint Valley-Saline Valley pull-apart system, California; palinspastic evidence for low-angle geometry of a Neogene range-bounding fault. J. Geophys. Res., 92: 10422-10426.

Chéry, J., 2001. Core complex mechanics: From the gulf of Corinth to the Snake Range. Geology, 29(5): 439-442.

Clément, C., 2000. Imagerie sismique crustale de la subduction Hellènique et du golfe de Corinthe, Université Paris 7, Paris, 178 pp.

Clément, C., Sachpazi, M., Charvis, P., Graindorge, D., Laigle, M., Hirn, A. and Zafiropoulos, G., 2004. Reflection-refraction seismics in the Gulf of Corinth: hints at deep structure and control of the deep marine basin. Tectonophysics, 391: 85-95.

Colletta, B., Quellec, P.L., Letouzey, J. and Moretti, I., 1987. Longitudinal evolution of the Suez rift (Egypt). Tectonophysics, 153: 221-233. 
Collettini, C. and Holdsworth, R.E., 2004. Fault zone weakening and character of slip along low-angle normal faults: insights from the Zuccale fault, Elba, Italy. J. Geol. Soc. London, 161: 1039-1051.

Collier, R.E.L., 1990. Eustatic and tectonic controls upon Quaternary coastal sedimentation in the Corinth Basin, Greece. J. geol. soc. London, 147: 301-314.

Collier, R.E.L., Leeder, M.R., Rowe, R.J. and Atkinson, T.C., 1992. Rates of tectonic uplift in the Corinth and Megara basins, Central Greece. Tectonics, 11: 1159-1167.

Coney, P.J. and Harms, T.A., 1984. Cordilleran metamorphic core complexes, Cenozoic extensional relics of Mesozoic compression. Geology, 12: 550-554.

Cornet, F., Bernard, P. and Moretti, I., 2004a. The Corinth Rift Laboratory. Comptes Rendus Geoscience, 336(4-5): 235-242.

Cornet, F.H., Doan, M.L., Moretti, I. and Bormc, G., 2004b. Drilling through the active Aigion Fault: the AIG10 well observatory C. R. Geosciences, 336: 395-406.

Creutzburg, N., 1977. General geological map of Greece. Crete island. 1:200 000. Institute of Geological and Mining Research, Athens.

Davis, G.H., 1983. Shear-zone model for the origin of metamorphic core complexes. Geology, 11: 342-347.

Dercourt, J., Zonenshain, L.P., Ricou, L.E., Kuzmin, V.G., Le Pichon, X., Knipper, A.L., Grandjacquet, C., Sbortshikov, I.M., Geyssant, J., Lepvrier, C., Pechersky, D.H., Boulin, J., Sibuet, J.C., Savostin, L.A., Sorokhtin, O., Westphal, M., Bazhenov, M.L., Lauer, J.P. and Biju-Duval, B., 1986. Geological evolution of the Tethys belt from the Atlantic to the Pamir since the Lias. Tectonophysics, 123: 241-315.

Duchêne, S., Aïssa, R. and Vanderhaeghe, O., 2006. Pressure-Temperature-time Evolution of Metamorphic Rocks from Naxos (Cyclades, Greece): constraints from Thermobarometry and Rb/Sr dating Geodynamica Acta, 19(5): 299-319.

Famin, V., Hébert, R., Philippot, P. and Jolivet, L., 2005. Ion probe and fluid inclusion evidences for co-seismic fluid infiltration in a crustal detachment. Contrib. Mineral. Petrol., 150(3): 354-367, DOI 10.1007/s00410-005-0031-x.

Famin, V., Nakashima, S., Jolivet, L. and Philippot, P., 2004a. Mobility of metamorphic fluids inferred from Infrared microspectroscopy on natural fluid-inclusions. An example from Tinos Island (Greece). Contrib. Mineral. Petrol., 146: 736-749. 
Famin, V., Philippot, P., Jolivet, L. and Agard, P., 2004b. Evolution of hydrothermal regime along a crustal shear zone, Tinos island, Greece. Tectonics, 23: doi:10.1029/2003TC001509.

Fassoulas, C., Kilias, A. and Mountrakis, D., 1994. Postnappe stacking extension and exhumation of high-pressure/low-temperature rocks in the island of Crete, Greece. Tectonics, 13: 127-138.

Faure, M., Bonneau, M. and Pons, J., 1991. Ductile deformation and syntectonic granite emplacement during the late Miocene extension of the Aegean (Greece). Bull. Soc. géol. France, 162: 3-12.

Flerit, F., Armijo, R., King, G. and Meyer, B., 2004. The mechanical interaction between the propagating North Anatolian Fault and the back-arc extension in the Aegean. Earth Planet. Sci. Lett., 224: 347-362.

Flotté, N. and Sorel, D., 2001. Structural cross-section through the Corinth-Patras detachment fault-system in northern Peloponnesus (Aegean arc, Greece). Bull. Soc. Geol. Greece, XXXIV/1: 235-241.

Flotté, N., Sorel, D., Müller, C. and Tensi, J., 2005. Along strike changes in the structural evolution over a brittle detachment fault: Example of the Pleistocene Corinth-Patras rift (Greece). Tectonophysics, 403: 77-94.

Ford, M., Williams, E.A., malartre, F. and Popescu, S.P., 2007. Stratigraphic architecture, sedimentology and structure of the Vouraikos Gilbert-type delats, Gulf of Corinth, Greece. In: C. Paola, G.J. Nichols and E.A. Williams (Editors), I. A. S. Special Publication.

Garcès, M. and Gee, J.S., 2007. Paleomagnetic evidence of large footwall rotations associated with low-angle faults at the Mid-Atlantic Ridge. Geology, 35(3): 279-282.

Gautier, P., 1994. Géométrie crustale et cinématique de l'extension tardi-orogénique dans le domaine centre-égéen (iles des Cyclades et d'Eubée, Grèce). Thesis Thesis, Université de Rennes.

Gautier, P. and Brun, J.P., 1994a. Crustal-scale geometry and kinematics of late-orogenic extension in the central Aegean (Cyclades and Evvia island). Tectonophysics, 238: 399-424. 
Gautier, P. and Brun, J.P., 1994b. Ductile crust exhumation and extensional detachments in the central Aegean (Cyclades and Evvia islands). Geodinamica Acta, 7(2): 57-85.

Gautier, P., Brun, J.P. and Jolivet, L., 1993. Structure and kinematics of upper Cenozoic extensional detachement on Naxos and Paros (Cyclades Islands, Greece). Tectonics, 12: $1180-1194$.

Gautier, P., Brun, J.P., Moriceau, R., Sokoutis, D., Martinod, J. and Jolivet, L., 1999. Timing, kinematics and cause of Aegean extension: a scenario based on a comparison with simple analogue experiments. Tectonophysics, 315(1-4): 31-72.

Gautier, S., Latorre, D., Virieux, J., Deschamps, A., Skarpelos, C., Sotiriou, A., Serpetsidaki, A. and Tselentis, A., 2006. A New Passive Tomography of the Aigion Area (Gulf of Corinth, Greece) from the 2002 Dataset. Pure Applied Geophys., DOI 10.1007/s00024-005-0033-7.

Ghisetti, F. and Vezzani, L., 2002. Normal faulting, transcrustal permeability and seismogenesis in the Apennines (Italy). Tectonophysics, 348(155-168).

Ghisetti, F. and Vezzani, L., 2005. Inherited structural controls on normal fault architecture in the Gulf of Corinth (Greece). Tectonics, 24(TC4016): doi:10.1029/2004TC001696.

Goldworthy, M. and Jackson, J., 2001. Migration of activity within normal fault systems: examples from the Quaternary of mainland Greece. J. Struct. Geol., 23: 489-506.

Gueydan, F., Leroy, Y. and Jolivet, L., 2004. Mechanics of low-angle extensional shear zones at the brittle-ductile transition. J. Geophys. Res., 109(B12407): doi:10.1029/2003JB002806.

Gueydan, F., Leroy, Y., Jolivet, L. and Agard, P., 2003. Analysis of continental midcrustal strain localization induced by microfracturing and reaction-softening. J. Geophys. Res., 108(B2): ETG 1-1, doi:10.1029/2001JB000611.

Hatzfeld, D., Karakostas, V., Ziazia, M., Kassaras, I., Papadimitriou, E., Makropoulos, K., Voulgaris, N. and Papaioannou, C., 2000. Microseismicity and faulting geometry in the Gulf of Corinth (Greece). Geophys. J. Int., 141: 438-456.

Hayman, N.W., Knott, J.R., Cowan, D.S., Nemser, E. and Sarna-Wojcicki, A.M., 2003. Quaternary low-angle slip on detachement faults in Death Valley, California. Geology, 31(4): 343-346. 
Hetzel, R., Passchier, C.W., Ring, U. and Dora, O.O., 1995. Bivergent extension in orogenic belts: the Menderes massif (southwestern Turkey). Geology, 23: 455-458.

Higgs, B., 1988. Syn-sedimentary structural controls on basin formation in the Gulf of Corinth, Greece. Basin Research, 1: 155-165.

Houghton, S.L., Roberts, G.P., Papanikolaou, I.D., McArthur, J.M. and Gilmour, M.A., 2003. New 234U-230Th coral dates from the western Gulf of Corinth: Implications for extensional tectonics. Geophys Res. Lett., 30(19): 2013, doi:10.1029/2003GL018112,.

Jackson, J., 1994. Active tectonics of the Aegean region. Annu. Rev. Earth Planet. Sci., 22: 239-271.

Jackson, J.A., Gagnepain, J., Houseman, G., King, G.C.P., Papadimitriou, P., Soufleris, C. and Virieux, J., 1982. Seismicity, normal faulting and the geomorphological development of the Gulf of Corinth (Greece): the Corinth earthquakes of February and March 1981. Earth Planet. Sci. Lett., 57: 377-397.

Jackson, J.A. and White, N.J., 1989. Normal fauting in the upper continental crust: observations from regions of active extension. J. Struct. Geol., 11(1/2): 15-36.

Jacobshagen, V., Dürr, S., Kockel, F., Kopp, K.O., Kowalczyk, G., Berckhemer, H. and Büttner, D., 1978. Structure and geodynamic evolution of the Aegean region. In: H. Cloos, D. Roeder and K. Schmidt (Editors), Alps, Apennines, Hellenides. IUGG, Stuttgart, pp. 537-564.

Jansen, J.B.H. and Schuilling, R., 1976. Metamorphism on Naxos: petrology and geothermal gradient. Am. J. Science, 276: 1225-1253.

Jolivet, L., 2001. A comparison of geodetic and finite strain in the Aegean, geodynamic implications. Earth Planet. Sci. Lett., 187: 95-104.

Jolivet, L. and Brun, J.P., 2008. Cenozoic geodynamic evolution of the Aegean region. Int. J. Earth Science, in press: DOI: 10.1007/s00531-008-0366-4.

Jolivet, L., Brun, J.P., Gautier, P., Lallemant, S. and Patriat, M., 1994a. 3-D kinematics of extension in the Aegean from the Early Miocene to the Present, insight from the ductile crust. Bull. Soc. géol. France, 165: 195-209.

Jolivet, L., Daniel, J.M., Truffert, C. and Goffé, B., 1994b. Exhumation of deep crustal metamorphic rocks and crustal extension in back-arc regions. Lithos, 33(1/2): 3-30. 
Jolivet, L. and Faccenna, C., 2000. Mediterranean extension and the Africa-Eurasia collision. Tectonics, 19(6): 1095-1106.

Jolivet, L., Faccenna, C., Goffé, B., Burov, E. and Agard, P., 2003. Subduction tectonics and exhumation of high-pressure metamorphic rocks in the Mediterranean orogens. Am. J. Science, 303: 353-409.

Jolivet, L., Faccenna, C., Goffé, B., Mattei, M., Rossetti, F., Brunet, C., Storti, F., Funiciello, R., Cadet, J.P. and Parra, T., 1998a. Mid-crustal shear zones in post-orogenic extension: the northern Tyrrhenian Sea case. J. Geophys. Res., 103(B6): 12123-12160.

Jolivet, L., Famin, V., Mehl, C., Parra, T., Aubourg, C., Hébert, R. and Philippot, P., 2004. Progressive strain localisation, boudinage and extensional metamorphic complexes, the Aegean Sea case. In: D.L. Whitney, C. Teyssier and C.S. Siddoway (Editors), Gneiss domes in orogeny. Geological Society of America Special Paper 380. Geological Society of America, Boulder, Colorado, pp. 185-210.

Jolivet, L., Goffé, B., Bousquet, R., Oberhänsli, R. and Michard, A., 1998b. Detachements in high pressure mountains belts, Tethyan examples. Earth Planet. Sci. Lett., 160: 31-47.

Jolivet, L., Goffé, B., Monié, P., Truffert-Luxey, C., Patriat, M. and Bonneau, M., 1996. Miocene detachment in Crete and exhumation P-T-t paths of high pressure metamorphic rocks. Tectonics, 15(6): 1129-1153.

Jolivet, L. and Patriat, M., 1999. Ductile extension and the formation of the Aegean Sea. In: B. Durand, L. Jolivet, F. Horvàth and M. Séranne (Editors), The Mediterranean basins: tertiary extension within the Alpine orogen. Geological Society Special Publication. Geological Society, London, pp. 427-456.

Jolivet, L., Trotet, F., Monié, P., Vidal, O., Goffé, B., Labrousse, L., Agard, P. and Ghorbal, B., 2009. Along-strike variations of P-T conditions in accretionary wedges and synorogenic extension, the HP-LT Phyllite-Quartzite Nappe in Crete and the Peloponnese. Tectonophysics, in revision.

Keraudren, B. and Sorel, D., 1987. The terraces of Corinth (Greece) - adetailed record of eustatic sea-level variations during the last 500,000 years. Mar. Geol., 77: 99-107.

Kilias, A., Fassoulas, H. and Mountrakis, D., 1994. Tertiary extension of continental crust and exhumation of Psiloritis "metamorphic core complex" in the central part of the Hellenic arc (Crete, Greece). Geol. Rundshau, 83: 417-430. 
King, G., Ouyang, Z., Papadimitriou, P., Deschamps, A., Gagnepain, A., Houseman, G., Jackson, J., Soufleris, C. and Virieux, J., 1985. The evolution of the Gulf of Corinth (Greece) an aftershock study of the 1981 earthquake. Geophys. J. R. Astron. Soc., 80: 677-693.

Klemperer, S.L., 1988. Crustal thinning and nature of extension in the northern North Sea from deep seismic reflection profiling. Tectonics, 4: 803-821.

Koukouvelas, I.K. and Aydin, A., 2002. fault structure and related basins of the North Aegean Sea and its surroundings. Tectonics, 21(5): 1046, doi:10.1029/2001TC901037.

Kreemer, C. and Chamot-Rooke, N., 2004. Contemporary kinematics of the southern Aegean and the Mediterranean Ridge. Geophys. J. Int., 157: 1377-1392.

Kreemer, C., Chamot-Rooke, N. and Le Pichon, X., 2004. Constraints on the evolution and vertical coherency of deformation in the Northern Aegean from a comparison of geodetic, geologic and seismologic data. Earth and Planetary Science Letters, 225: 329-346.

Kusznir, N.J. and Park, R.G., 1987. The extensional strength of the continental lithosphere: its dependance on geothermal gradient, and crustal composition and thickness. In: M.P. Coward, J.F. Dewey and P.L. Hancock (Editors), Continental Extensional Tectonics. Geological Society Special Publication, pp. 35-52.

Laigle, M., Hirn, A., Sachpazi, M. and Roussos, N., 2000. North Aegean crustal deformation: an active fault imaged to $10 \mathrm{~km}$ depth by reflection seismic data. Geology, 28(1): 7174.

Lecomte, E., Jolivet, L., Lacombe, O., Denèle, Y., Labrousse, L. and Le Pourhiet, L., 2009. Geometry and kinematics of a low-angle normal fault on Mykonos island (Cyclades, Greece). submitted.

Le Pichon, X., 1982. Land-locked oceanic basins and continental collision, the eastern Mediterranean as a case example. In: K.J. Hsue (Editor), Mountain Building processes. Academic press, London, pp. 201-211.

Le Pichon, X. and Angelier, J., 1979. The Hellenic arc and trench system: a key to the neotectonic evolution of the eastern Mediterranean area. Tectonophysics, 60: 1-42. 
Le Pichon, X., Chamot-Rooke, N., Lallemant, S.L., Noomen, R. and Veis, G., 1995. Geodetic determination of the kinematics of Central Greece with respect to Europe: implications for eastern Mediterranean tectonics. J. Geophys. Res., 100: 12675-12690.

Le Pichon, X., Chamot-Rooke, N., Rangin, C. and Sengor, A.M.C., 2003. The North Anatolian Fault in the Sea of Marmara. J. Geophys. Res., 108: doi:10.1029/2002JB001862.

Le Pourhiet, L., Burov, E. and Moretti, I., 2004. Rifting through a stack of inhomogeneous thrusts (the dipping pie concept). Tectonics, 23(TC4005): doi:10.1029/2003TC001584.

Le Pourhiet, L., Mattioni, L. and Moretti, I., 2006. 3D modelling of rifting through a preexisting stack of nappes in the Gulf of Corinth (Greece) a mixed analogue/numerical approach. In: S.J.H. Buiter and G. Schreurs (Editors), Analogue and numerical modelling of crustal-scale processes. Special Publications. Geological Society, London, pp. 233-252.

Leeder, M.R., Mack, G.H., Brasier, A.T., Parrish, R.R., McIntosh, W.C., Andrews, J.E. and Duermeijer, C.E., 2008. Late-Pliocene timing of Corinth (Greece) rift-margin fault migration. Earth and Pl. Sc. Letters, 274: 132-141; doi:10.1016/j.epsl.2008.07.006

Lister, G.S., Banga, G. and Feenstra, A., 1984. Metamorphic core complexes of cordilleran type in the Cyclades, Aegean Sea, Greece. Geology., 12: 221-225.

Lister, G.S. and Davis, G.A., 1989. The origin of metamorphic core complexes and detachment faults formed during Tertiary continental extension in the northern Colorado River region, U.S.A. Journal of Structural Geology, 11(1/2): 65-94.

Lister, G.S., Etheridge, M.A. and Symonds, P.A., 1986. Detachment faulting and the evolution of passive continental margins. Geology, 14: 246-250.

Lyon-Caen, H., Armijo, R., Drakopoulos, J., Baskoutass, J., Delibassis, N., Gaulon, R., Kouskouna, V., Latoussakis, K., Makropoulos, K., Papadimitriou, P., Papanastassiou, D. and Pedotti, G., 1988. The 1986 Kalamata (South Peloponnesus) earthquake: detailed study of a normal fault, evidences for E-W extension in the Hellenic Arc. $J$. Geophys. Res., 93: 14967-15000. 
Lyon-Caen, H., Papadimitriou, P., Deschamps, A., Bernard, P., Makropoulos, K., Pacchiani, F. and Patau, G., 2004. First results of the CRLN seismic network in the western orinth Rift: evidence for old fault reactivation. C. R. Geoscience, 336: 343-351.

Mattei, M., d'Agostino, N., Zanarini, I., Kondopoulou, D., Pavlides, S. and Spatharas, V., 2004. Tectonic evolution of fault-bounded continental blocks: comparison of paleomagnetic and GPS data in the Corinth and Megara basins (Greece). J. Geophys. Res., 109: B02115, doi:10.1029/2003JB002506.

McClusky, S., Balassanian, S., Barka, A., Demir, C., Ergintav, S., Georgiev, I., Gurkan, O., Hamburger, M., Hurst, K., Kahle, H., Kastens, K., Kekelidze, G., king, R., Kotzev, V., Lenk, O., Mahmoud, S., Mishin, A., Nadariya, M., Ouzonis, A., Paradissis, D., Peter, Y., Prilepin, M., Reilinger, R., Sanli, I., Seeger, H., Tealeb, A., Toksöz, M.N. and Veis, G., 2000. Global Positioning System constraints on plate kinematics and dynamics in the eastern Mediterranean and Caucasus. J. Geophys. Res., 105: 56955720 .

McKenzie, D., 1972. Active tectonics in the Mediterranean region. Geophys. J. R. astr. Soc., 30: 109-185.

McKenzie, D., 1978. Active tectonics of the Alpine-Himalayan belt: the Aegean Sea and surrounding regions. Geophys. J. R. astr. Soc., 55: 217-254.

McNeill, L.C. and Collier, R.E.L., 2004. Uplift and slip rates of theEastern Eliki fault segment,Gulf ofCorinth,Greece, inferred from Holocene and Pleistocene terraces. J. Geol. Soc. Lond., 161: 81-92.

McNeill, L.C., Collier, R.E., DeMartini, P.M., Pantosti, D. and D'Addezio, G., 2005a. Recent history of the Eastern Eliki Fault, Gulf of Corinth: geomorphology, palaeosismology and impact on palaeoenvironments. Geoph. Jour. Intern., 161: 154-166.

McNeill, L.C., Cotterill, C.J., Henstock, T.J., Bull, J.M., Stefatos, A., Collier, R.E.L., Papatheoderou, G., G.Ferentinos and Hicks, S.E., 2005b. Active faulting within the offshore western Gulf of Corinth, Greece: Implications for models of continental rift deformation. Geology, 33(4): 241-244.

Mehl, C., Jolivet, L. and Lacombe, O., 2005. From ductile to brittle: evolution and localization of deformation below a crustal detachment (Tinos, Cyclades, Greece). tectonics, 24: TC4017, doi:10.1029/2004TC001767. 
Mehl, C., Jolivet, L., Lacombe, O., Labrousse, L. and Rimmelé, G., 2007. Structural evolution of Andros island (Cyclades, Greece): a key to the behaviour of a flat detachment within an extending continental crust. In: T. Taymaz, Y. Dilek and Y. Ylmaz (Editors), The geodynamics of the Aegean and Anatolia. Special Publications. Geological Society, London, pp. 41-73, DOI: 10.1144/SP291.3 0305-8719/07/\$15.00.

Moretti, I., Sakellariou, D., Lykoussis, V. and Micarelli, L., 2003. The Gulf of Corinth: a half graben ? J. Geodynamics, 36: 323-340.

Morrison, J. and Anderson, J.L., 1998. Footwall refrigeration along a detachment fault: implications for the thermal evolution of core complexes. Science, 279: 63-66.

Nyst, M. and Thatcher, W., 2004. New constraints on the active deformation of the Aegean. J. Geophys. Res., 109(B11406): doi:10.1029/2003JB002830.

Ori, G.G., 1989. Geologic history of the extensional basin of the Gulf of Corinth (?MiocenePleistocene), Greece. Geology, 17: 918-921.

Palyvos, N., Pantosti, D., De Martini, P.M., Lemeille, F., Sorel, D. and Pavlopoulos, K., 2005. The Aigio-Neos Erineos coastal normal fault system (western Corinth Gulf Rift, Greece) geomorphological signature, recent earthquake history, and evolution. J. Geoph. Res., 110: B09302, doi:10.029/2004JB003165.

Papanikolaou, D., Gouliotis, L. and Triantaphyllou, M., 2009. The Itea-Amfissa detachment: a pre-Corinth rift Miocene extensional structure in central Greece. In: D.J.J. van Hinsbergen, M.A. Edwards and R. Govers (Editors), Collision and Collapse at the Africa-Arabia-Eurasia subduction zone, Geological Society of London Special Publication, pp. 293-310.

Papanikolaou, D.J. and Royden, L.H., 2007. Disruption of the Hellenic arc: Late Miocene extensional detachment faults and steep Pliocene-Quaternary normal faults-Or what happened at Corinth? Tectonics 26, TC5003, doi:10.1029/2006TC002007.

Papazachos, B.C. and Papazachos, C.B., 1989. The Earthquakes of Greece. Ziti Publications, Thessaloniki, Greece (in Greek).

Papazachos, C.B. and Kiratzi, A.A., 1992. A formulation for reliable estimation of active crustal deformation and its application to Central Greece. Geophys. J. Int., 111: 424432. 
Pi Alperin, J.M., Marthelot, J.M., Galvé, A., Sachpazi, M., Taylor, B., Laigle, M. and Hirn, A., 2004. Seismic refraction imaging of the southern Corinth Rift shoulder at Derveni. Comptes Rendus Géoscience, 336: 251-257.

Pik, R. and Marty, B., 2008. Helium isotopic signature of modern and fossil fluids associated with the Corinth rift fault zone (Greece): Implication for fault connectivity in the lower crust Chemical Geology, xxx: xxx-xxx, in press.

Platt, J.P., 1986. Dynamics of orogenic wedges and the uplift of high-pressure metamorphic rocks. Geological society of America Bulletin, 97: 1037-1053.

Purvis, M. and Robertson, A., 2004. A pulsed extension model for the Neogene-Recent E-Wtrending Alasehir Graben and the NE-SW-trending Selendi and Gördes Basins, western Turkey. Tectonophysics, 391: 171-201.

Rahl, J.M., Anderson, K.M., Brandon, M.T. and Fassoulas, C., 2005. Raman spectroscopic carbonaceous material thermometry of low-grade metamorphic rocks: Calibration and application to tectonic exhumation in Crete, Greece. Earth and Pl. Sc. Letters, 240: 339- 354 .

Rietbrock, A., Tibéri, C., Scherbaum, F. and Lyon-Caen, H., 1996. Seismic slip on a low angle normal fault in the Gulf of Corinth: Evidence from high resolution cluster analysis of microearthquakes. Geophys. Res. Lett., 23(14): 1817-1820.

Rigo, A., Lyon-Caen, H., Armijo, R., Deschamps, A., Hatzfeld, D., Makropoulos, K., Papadimitriou, P. and Kassaras, I., 1996. A microseismicity study in the western part of the Gulf of Corinth (Greece): implications for large-scale normal faulting mechanisms. Geophys. J. Int., 126: 663-688.

Ring, U., Brachert, T. and Fassoulas, C., 2001. Middle Miocene graben development in Crete and its possible relation to large-scale detachment faults in the southern Aegean. Terra Nova, 13: 297-304.

Ring, U. and Layer, P.W., 2003. High-pressure metamorphism in the Aegean, eastern Mediterranean: underplating and exhumation from the Late Cretaceous until the Miocene to Recent above the retreating Hellenic subduction zone. Tectonics, 22(3): doi: 10.1029/2001TC001350.

Roberts, G.P., 1996. Noncharacteristics normal faulting surface ruptures from the Gulf of Corinth, Greece. J. Geophys. Res., 101(B11): 25255-25267. 
Rohais, S., Eschard, R., Ford, M., Guillocheau, F. and Moretti, I., 2007a. Stratigraphic architecture of the Plio-Pleistocene infill of the Corinth Rift, implications for its structural evolution. Tectonophysics, 440: 5-28.

Rohais, S., Joannin, S., Colin, J.P., Suc, J.P., Guillocheau, F. and Eschard, R., 2007b. Age and environmental evolution of the syn-rift fill of the southern coast of the Gulf of Corinth (Akrata-Derveni region, Greece). Bull. Soc. Géol. France, 178(231 - 243).

Romano, S.S., Dörr, W. and Zulauf, G., 2004. Cambrian granitoids in pre-Alpine basement of Crete (Greece): evidence from U-Pb dating of zircon. Int J Earth Sci (Geol Rundsch), 93: 844-859, DOI 10.1007/s00531-004-0422-7.

Sachpazi, M., Clément, C., Laigle, M., Hirn, A. and Roussos, N., 2003. Rift structure, evolution, and earthquakes in the Gulf of Corinth, from reflection seismic images. Earth and Planetary Science Letters 216: 243-257.

Sanchez-Gomez, M., Avigad, D. and Heiman, A., 2002. Geochronology of clasts in allochthonous Miocene sedimentary sequences on Mykonos and Paros islands: implications for back-arc extension in the Aegean Sea. J. Geol. Soc. London, 159: 4560.

Seidel, E., Kreuzer, H. and Harre, W., 1982. The late Oligocene/early Miocene high pressure in the external hellenides. geol. Jb., E23: 165-206.

Seidel, M., Seidel, E. and Stöckhert, B., 2007. Tectono-sedimentary evolution of lower to middle Miocene half-graben basins related to an extensional detachment fault (western Crete, Greece). Terra Nova, 19(39-47, doi: 10.1111/j.1365-3121.2006.00707.x).

Sorel, D., 2000. A Pleistocene and still-active detachment fault and the origin of the CorinthPatras rift, Greece. Geology, 28: 83-86.

Taylor, B., Goodliffe, A.M., Weiss, J.R., Sachpazi, M., Hirn, A., Laigle, M. and Stefatos, A., 2003. Detachment tectonics in the Gulf of Corinth rift. Geophysical Research Abstracts, European Geophysical Society, April 2003, Nice, France, 5: Abstract no. 07222

Taylor, B. and Huchon, P., 2002. Active continental extension in the Western Woodlark Basin: a synthesis of Leg 180 results. In: P. Huchon, B. Taylor and A. Klaus (Editors), Proc. ODP, Sci. Results, pp. 1-36. 
Taymaz, T., Jackson, J. and McKenzie, D., 1991. Active tectonics of the north and central Aegean Sea. Geophys. J. Int., 106: 433-490.

Theye, T. and Seidel, E., 1991. Petrology of low grade high pressure metapelites from the external hellenides (Crete, Peloponese), a case study with attention to sodic minerals. Eur. J. Mineral., 3: 343-366.

Theye, T. and Seidel, E., 1993. Uplift-related retrogression history of aragonite marbles in western Crete (Greece). Contrib. Mineral. Petrol., 114: 349-356.

Theye, T., Seidel, E. and Vidal, O., 1992. Carpholite, sudoite and chloritoid in low highpressure metapelites from Crete and the peloponese, Greece. Eur. J. Mineral., 4: 487507.

Thomson, S.N., Stoeckhert, B. and Brix, M.R., 1998. Thermochronology of the high-pressure metamorphic rocks of Crete, Greece; implications for the speed of tectonic processes. Geology, 26(3): 259-262.

Tiberi, C., Diament, M., Lyon-Caen, H. and King, T., 2001. Moho topography beneath the Corinth rift area (Greece) from inversion of gravity data. Geophys. J. Int., 145: 797808.

Trotet, F., 2000. Exhumation des roches de haute pression - basse température le long d'un transect des Cyclades au Péloponnèse, implications géodynamiques. Thèse de doctorat Thesis, Université Paris XI, Orsay.

Trotet, F., Jolivet, L. and Vidal, O., 2001. Tectono-metamorphic evolution of Syros and Sifnos islands (Cyclades, Greece). Tectonophysics, 338: 179-206.

van Hinsbergen, D.J.J. and Meulenkamp, J.E., 2006. Neogene supradetachment basin development on Crete (Greece) during exhumation of the South Aegean core complex. Basin Research, 18: 103-124, doi: 10.1111/j.1365-2117.2005.00282.x.

Vanderhaeghe, O., 2004. Structural development of the Naxos migmatite dome. In: D.L. Whitney, C. Teyssier and C.S. Siddoway (Editors), Gneiss domes in orogeny. Geological Society of America, Boulder, Colorado, pp. 211-227.

Wernicke, B., 1981. Low-angle normal faults in the Basin and Range province: nappe tectonics in an extending orogen. Nature, 291: 645-648. 
Wernicke, B., 1992. Cenozoic extensional tectonics of the U.S. cordillera. In: B.C. Burchfiel, P.W. Lipman and M.L. Zoback (Editors), The Cordilleran Orogen: Conterminous U.S. Geological Society of America, Boulder, Colorado, pp. 553-581.

Wernicke, B., 1995. Low-angle normal faults and seismicity: a review. J. Geophys. Res., 100(B10): 20159-20174.

Wijbrans, J.R., van Wees, J.D., Stephenson, R.A. and Cloethingh, S.A.P.L., 1993. Pressuretemperature-time evolution of the high-pressure metamorphic complex of Sifnos, Greece. Geology, 21: 443-446.

Xypolias, P. and Doutsos, T., 2000. Kinematics of rock flow in a crustal-scale shear zone: implication for the orogenic evolution of the southwestern Hellenides. Geol. Mag., 137(1): 81-96.

Zulauf, G., Kowalczyk, G., Krahl, J., Petschick, R. and Schwanz, S., 2002. The tectonometamorphic evolution of high-pressure low-temperature metamorphic rocks of eastern Crete, Greece: constraints from microfabrics, strain, illite crystallinity and paleodifferential stress. J. Struct. Geol, 24: 1805-1828. 
Figure caption.

Figure 1: Tectonic map of the Corinth Rift showing the main faults, the distribution of syn-rif deposits onshore, the Zaroukla decollement, the Tyros Beds and the Phyllite-Quartzite nappe on a shaded topography and bathymetry made with GeoMapApp (Haxby et al.). The map is a compilation of several published works (Armijo et al., 1996; Flotté and Sorel, 2001; Ghisetti and Vezzani, 2005; McNeill et al., 2005a; b; Palyvos et al., 2005; Rohais et al., 2007a; Bell et al., 2008; Leeder et al., 2008). The broken line shows the position of figure 6 cross-section.

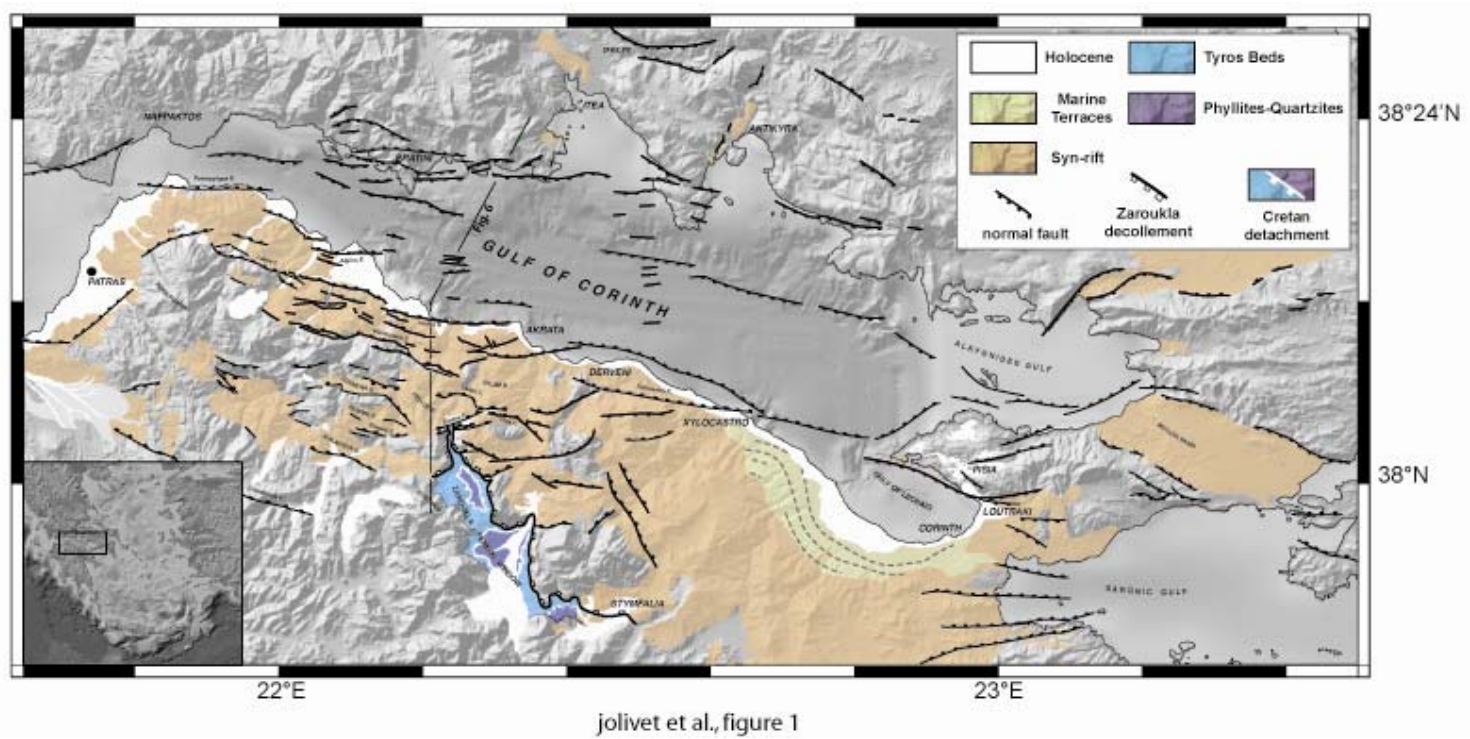

Figure 2: Comparison of two different extreme interpretations of the active Corinth Rift and the Naxos Oligo-Miocene metamorphic core complex. A: The Corinth Rift is controlled by one main north-dipping normal fault (Armijo et al., 1996). B: The Corinth Rift is controlled by one single north-dipping detachment (Sorel, 2000); seismicity after (Lyon-Caen et al. , 2004). C: Naxos metamorphic core complex after Gautier et al. (1993). 

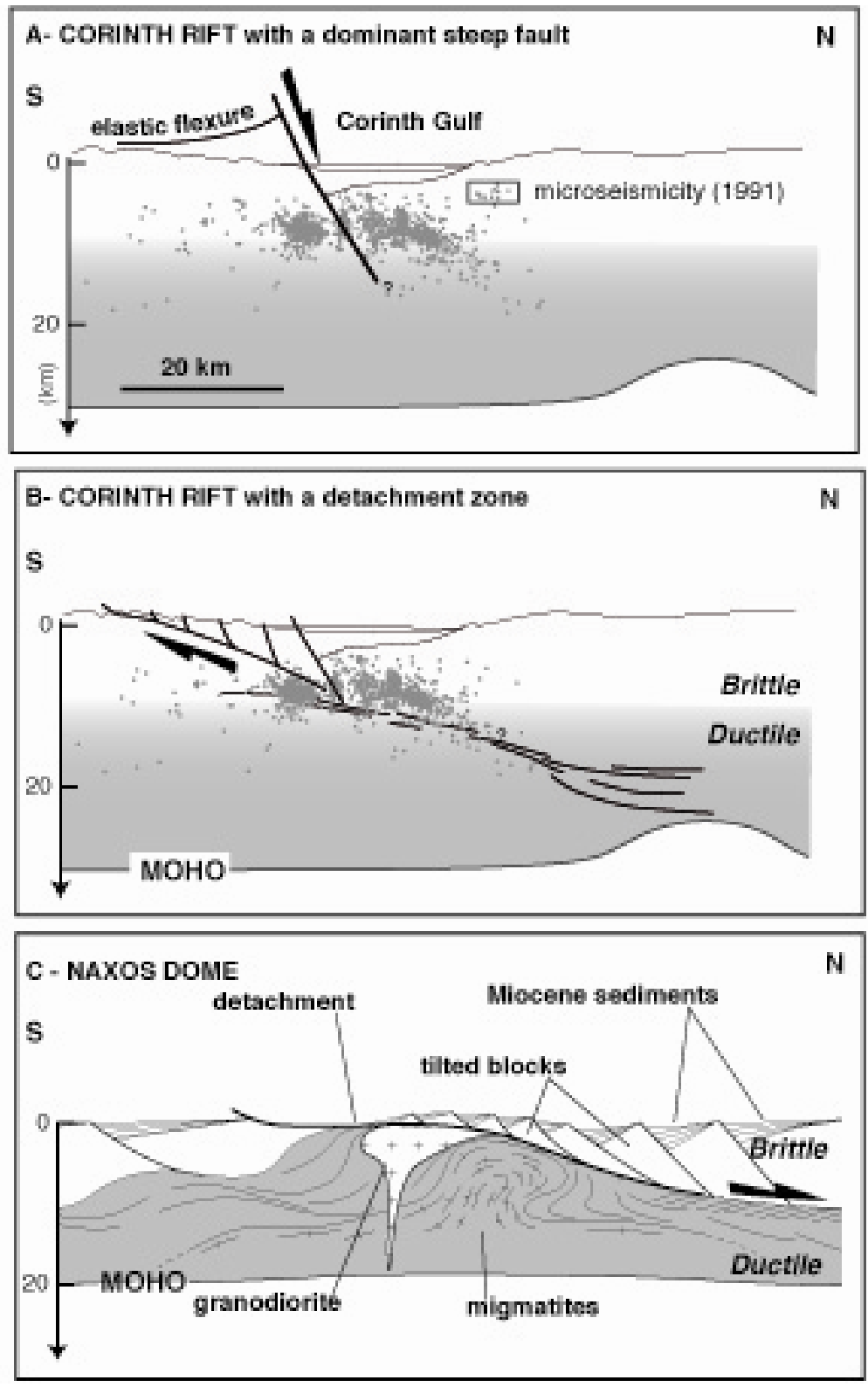

Figure 3: A: tectonic map of the Aegean region showing the main faults, and the main HP-LT metamorphic units of Cenozoic age, the Cycladic Blueschists and the PhylliteQuartzite nappe. 


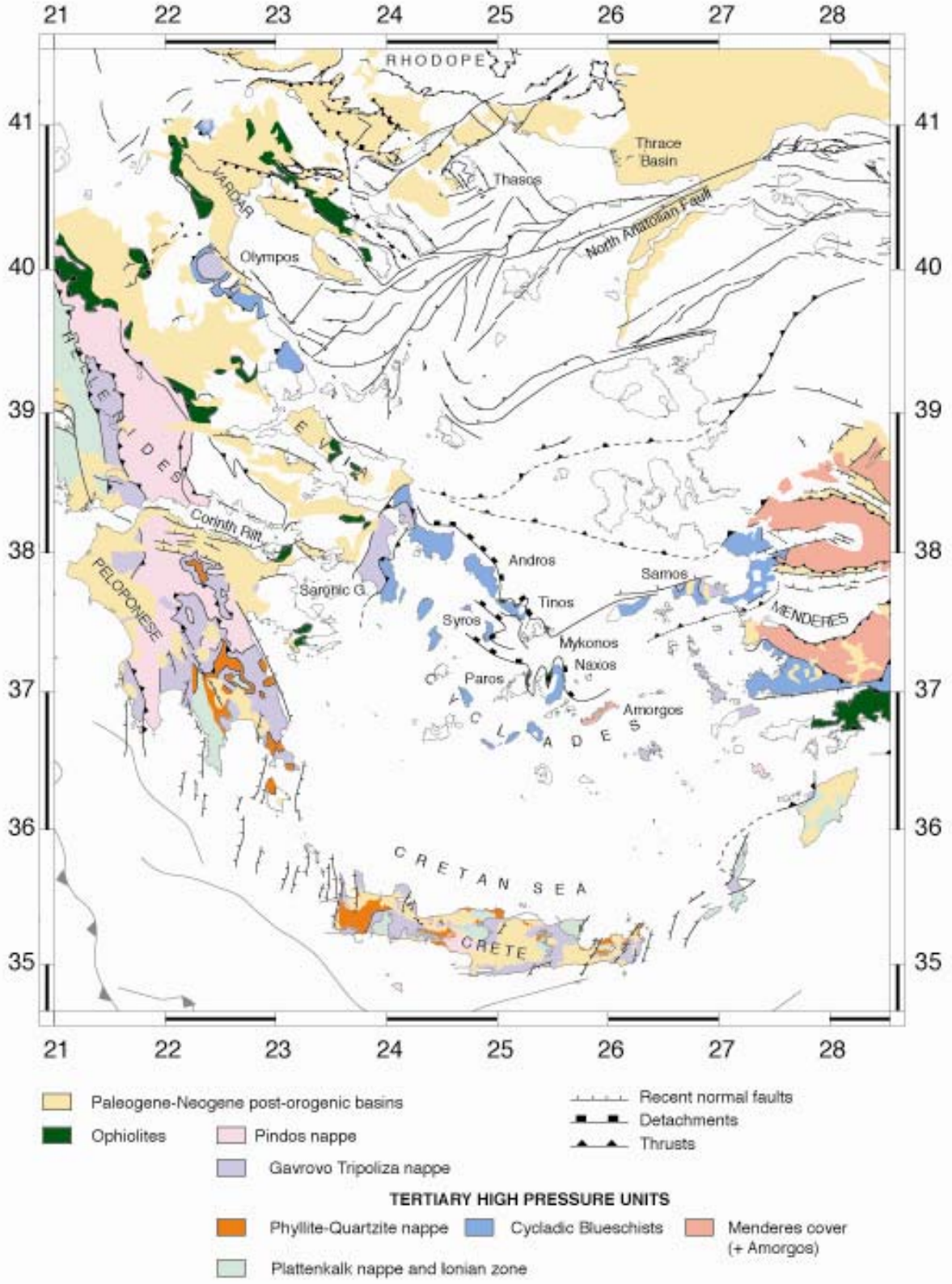


Figure 4: the high pressure and low temperature units in the Cyclades, Peloponnese and Crete and the strike of stretching lineations and sense of shear formed during the OligoMiocene (Jolivet et al., 2004 and references therein, Trotet et al., 2004, Huet et al., in press).

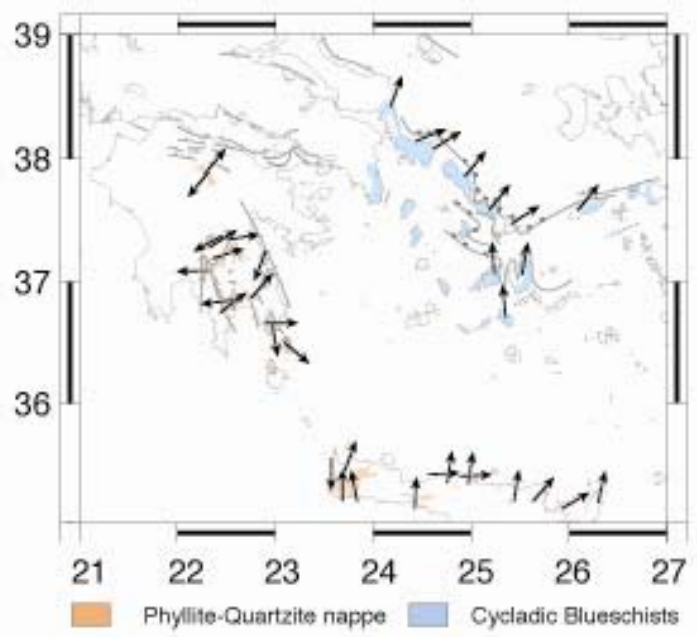

Figure 5: Geological map of the Aigion and Mt Kelmos region, simplified after Flotté et al. (2005). The geology of the Zaroukla-Feneos window is after our own survey. We distinguish the true metamorphic Phyllite-Quartzite nappe (lowermost unit) from the Tyros beds that make the lower part of the Gavrovo-Tripolitza nappe (see also Xypolias and Doutsos, 2000). (a) map of the Zaroukla-Feneos tectonic window showing the distribution of the Phyllite-Quartzite nappe and Tyros beds as well as the direction of retrograde stretching lineations and shear sense when available Small arrows represent the shear direction in the PQ nappe and the large arrow the transport 
direction on the Zaroukla detachment (next to black star). (b) Brecciated base of the Gavrovo-Tripolitza carbonates in the north of the window. Sketch of a roadside outcrop (localised by a black star on the map) showing a thick dolomitic limestone breccia with shallow-dipping normal faults cutting cohesive blocks. (c) Stereographic projection plot of normal faults and their striation on the same outcrop showing an overall N-S direction of stretching.

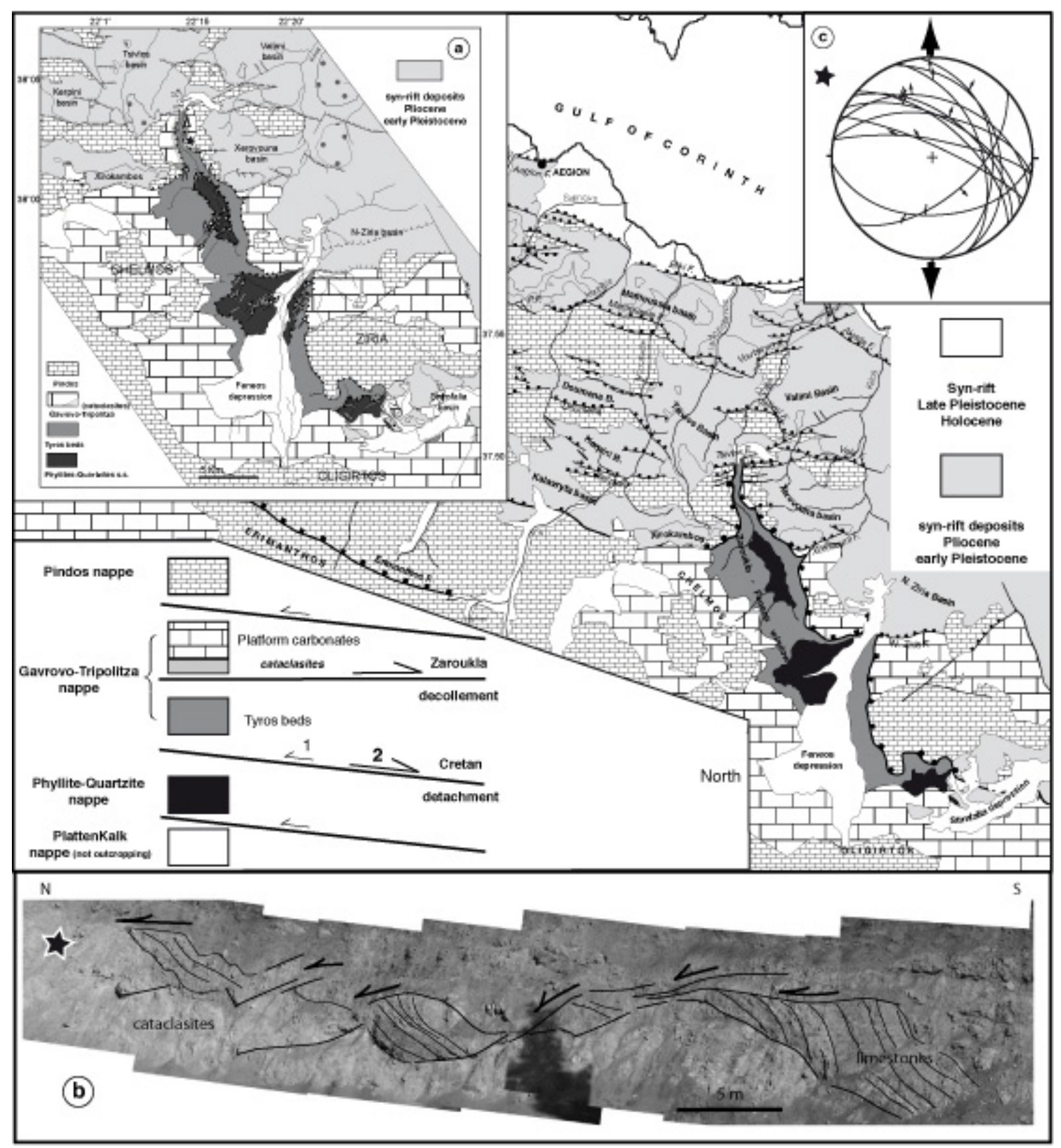

Jolivet et al., figure 5 
Figure 6: Interpretative balanced cross-sections through the Corinth Rift showing the relative positions of the movement zones observed or postulated onland (Sorel, 2000; Flotté and Sorel, 2001; Flotté et al., 2005), active normal faults cutting through the decollements on the southern shore (Armijo et al., 1996), the microseismicity zone (Rigo et al., 1996; Lyon-Caen et al., 2004) close to the brittle-ductile transition and the associated focal mechanisms (Rigo et al., 1996; Bernard et al., 1997; 2006), a zone of high fluid content shown by a detailed tomographic study (Gautier et al., 2006). (A) crustal-scale cross-section showing the three decollement levels (red lines) and the extension at depth of the brittle-ductile shear zone in the middle crust. The red dotted line is the outline of the fluid-rich zone inferred from seismic tomography (Gautier et al., 2006). (B) Details of the upper part of the section and the relations between the Zaroukla and Cretan detachments (TB: Tyros Beds, PQ: Phyllite-Quartzite).

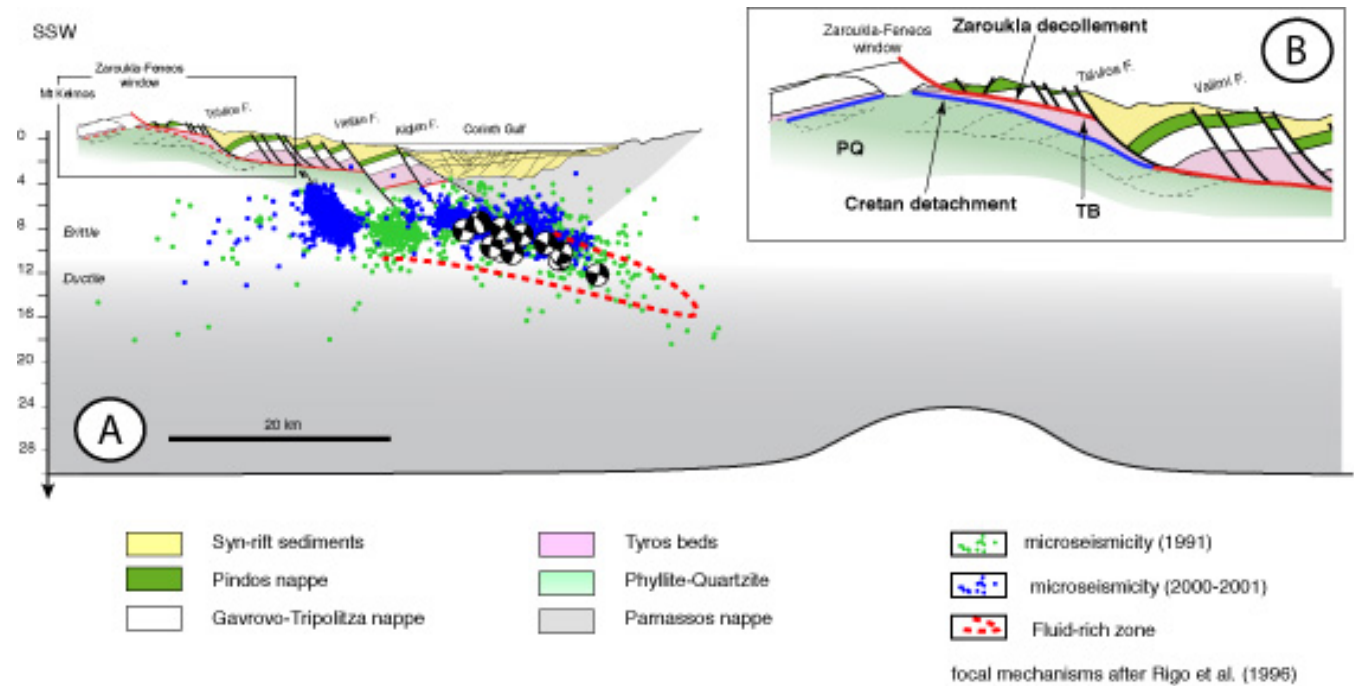

Figure 7: Restored cross-section of the upper crustal portion of the Corinth Rift. This part of the section has been balanced using the Pindos-Gavrovo-Tripolitza interface as a reference line. All blocks between normal faults are rigid except the block north of the Tsivlos fault that has been distorted to take into account the roll-over structure. 


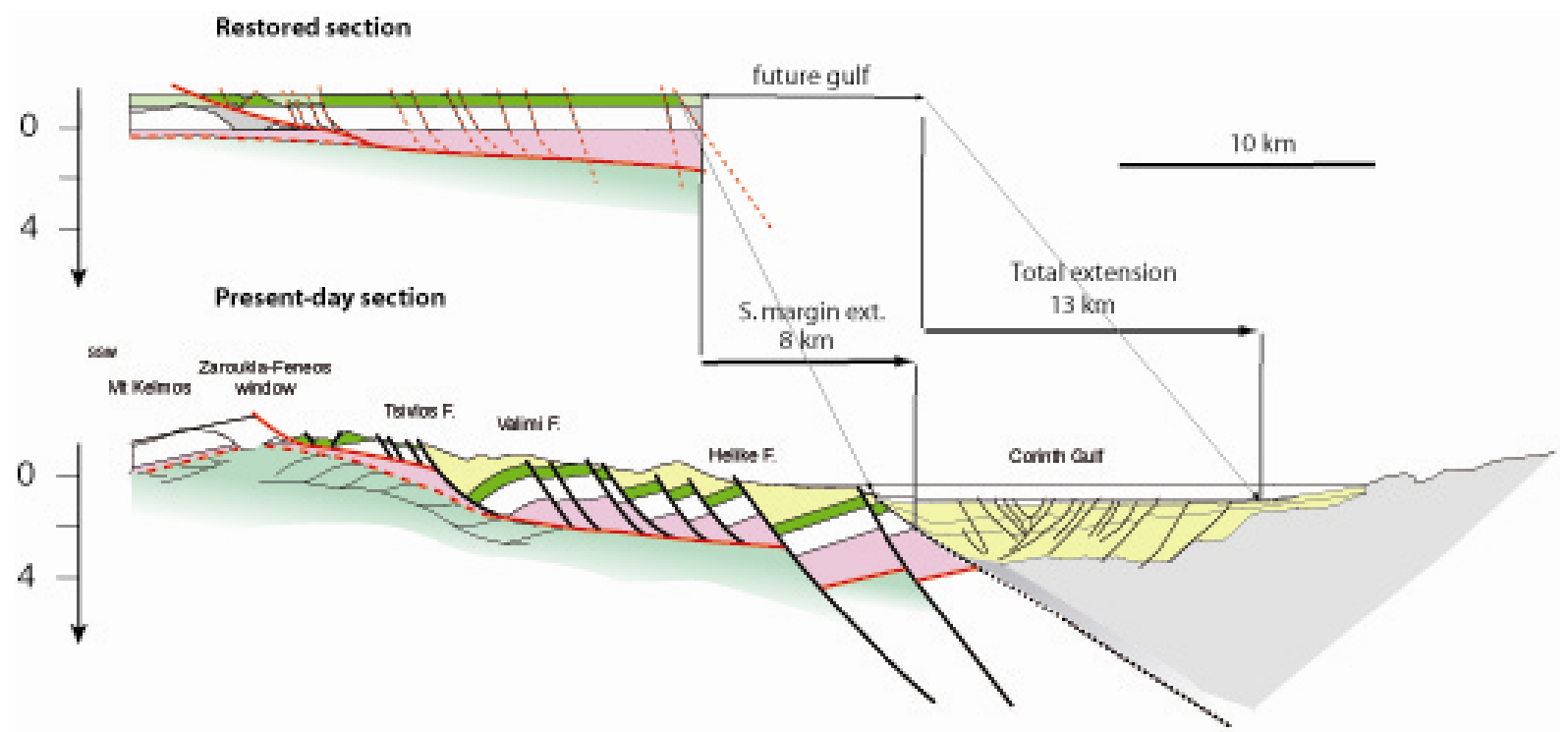

Figure 8: A complete crustal-section of the Corinth Rift using informations taken in exhumed deep equivalent of the Cyclades (see text for explanantion). Left is a scheme of the strength of such a profile with the three low-strength levels.

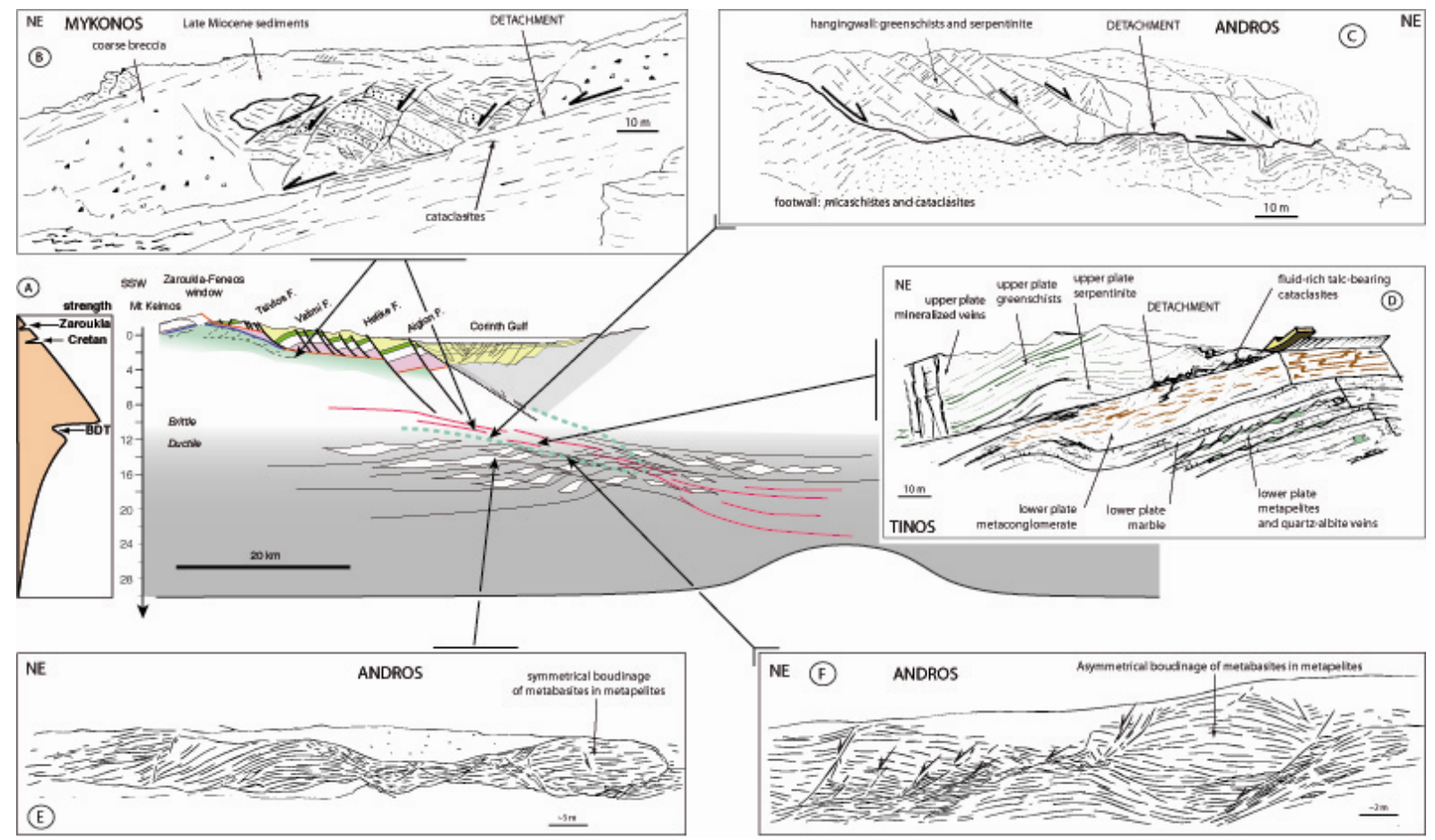

Figure 9: Photograph of steep normal faults cutting the hangingwall of the Tinos detachment (near Livada beach). The obvious normal faults all dip toward the northeast suggesting a component of top-to-the-northeast shear compatible with the kinematic indicators in the footwall. 


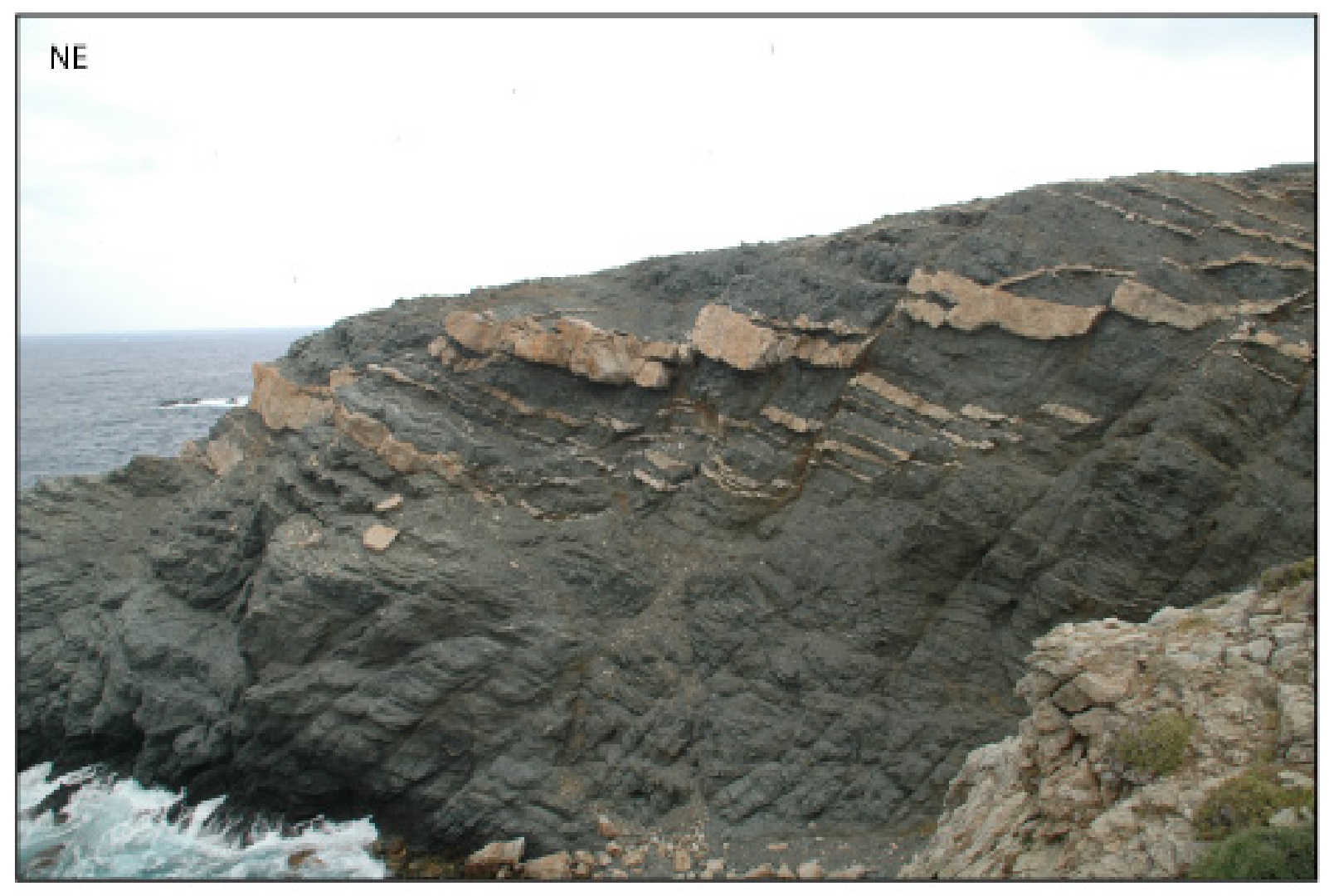

\section{Jolivet et al. figure 9}

Figure 10: Cross-section along the coast near Kolympithra on the NE coast of Tinos. The detachment is located between the upper plate made of serpentinite cropping out on a nearby islet and the lower plate here made essentially of micaschists and minor metabasites and marbles. A gradient of strain is observed from SW to NE and the deformation become more and more brittle through time. Shallow-dipping normal faults cut and offset the foliation (upper panel) and fluids invade the micaschists in the vicinity of the detachment. Numerous quartz veins are observed in the highly retrograded micaschists that evolve progressively into a reddish cataclasite. 


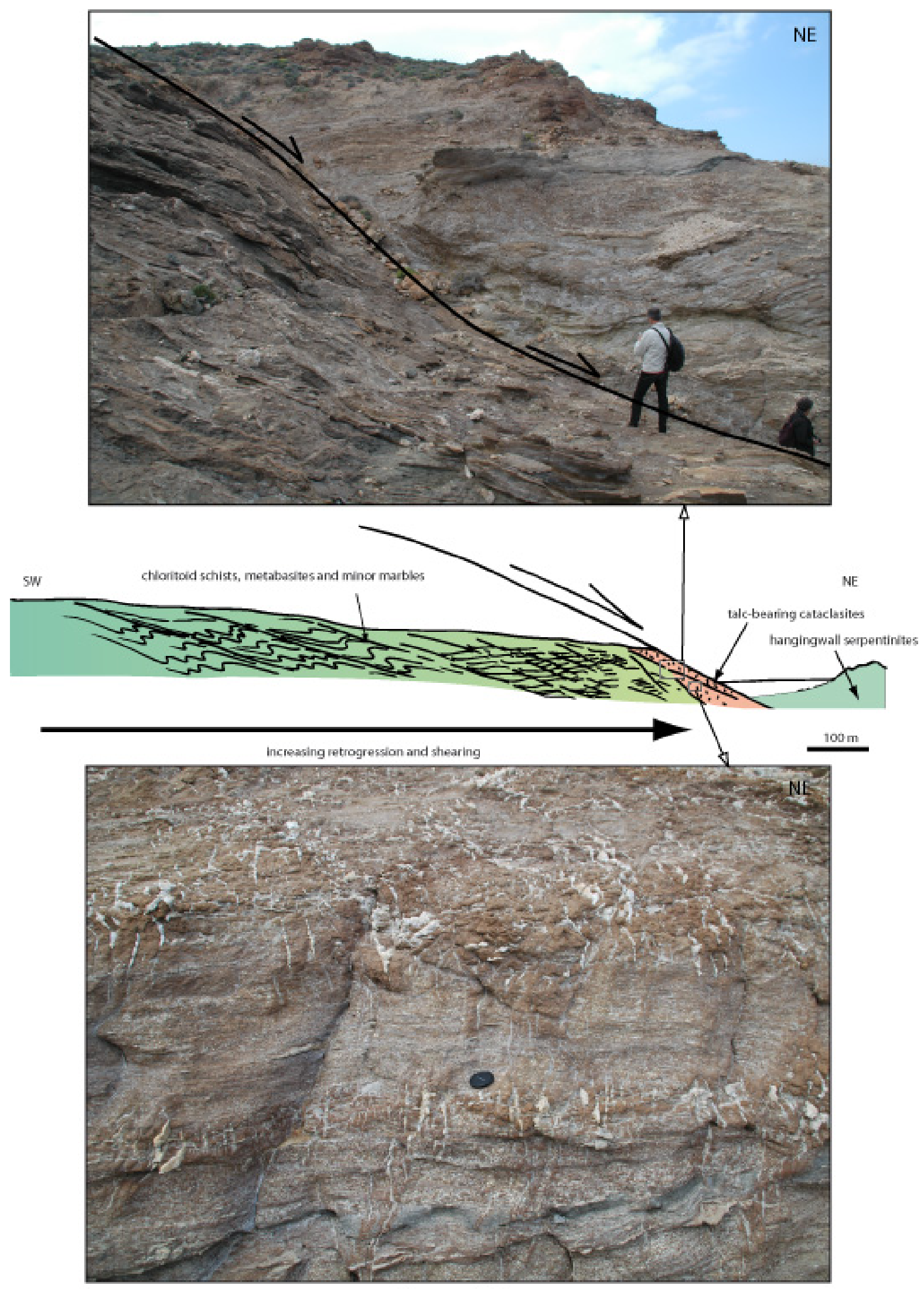

Jolivet et al., figure 10 
Figure 11: a possible evolution of the Corinth Rift from the pre-rift stage to the present and a speculative future evolution toward a metamorphic core complex. The pre-rift stage shows a possible structure after the exhumation of the Phyllite-Quartzite HP-LT rocks below a syn-orogenic detachment during the Oligo-Miocene. This first stage induces the formation of a dome and the eastern flank of this dome is reworked as an extensional shear zone during rifting. During the first rifting stages (from 3 to $1.5 \mathrm{Ma}$ ) extension is widely distributed along several normal faults that root on the detachment. The detachment is brittle in the upper crust with a thick zone of cataclasites . It becomes ductile across the brittle-ductile transition. From 1.5 Ma to 0.6-0.7 Ma extension tends to localise and faults become progressively extinct toward the north. 0.7 Ma ago, possibly because of an acceleration of extension, the presently active faults form on the southern shore of the Gulf and they reach deeper portions of the crust, down to the brittle-ductile transition. The northern Peloponnese, footwall of these faults, is flexed upward. The upper part of the detachment becomes extinct and the large faults root into an active decollement zone above and within the brittleductile transition. Cataclastic deformation above the brittle-ductile transition is manifested by the microseismicity recorded around Aigion. Further east the decollement is deeper and probably entirely ductile. The future evolution is based upon the assumption that the main normal faults seen today are transient structures and that the decollement continues its activity until the exhumation of the ductile crust and the formation of a metamorphic core complex similar to those observed in the Cyclades. 

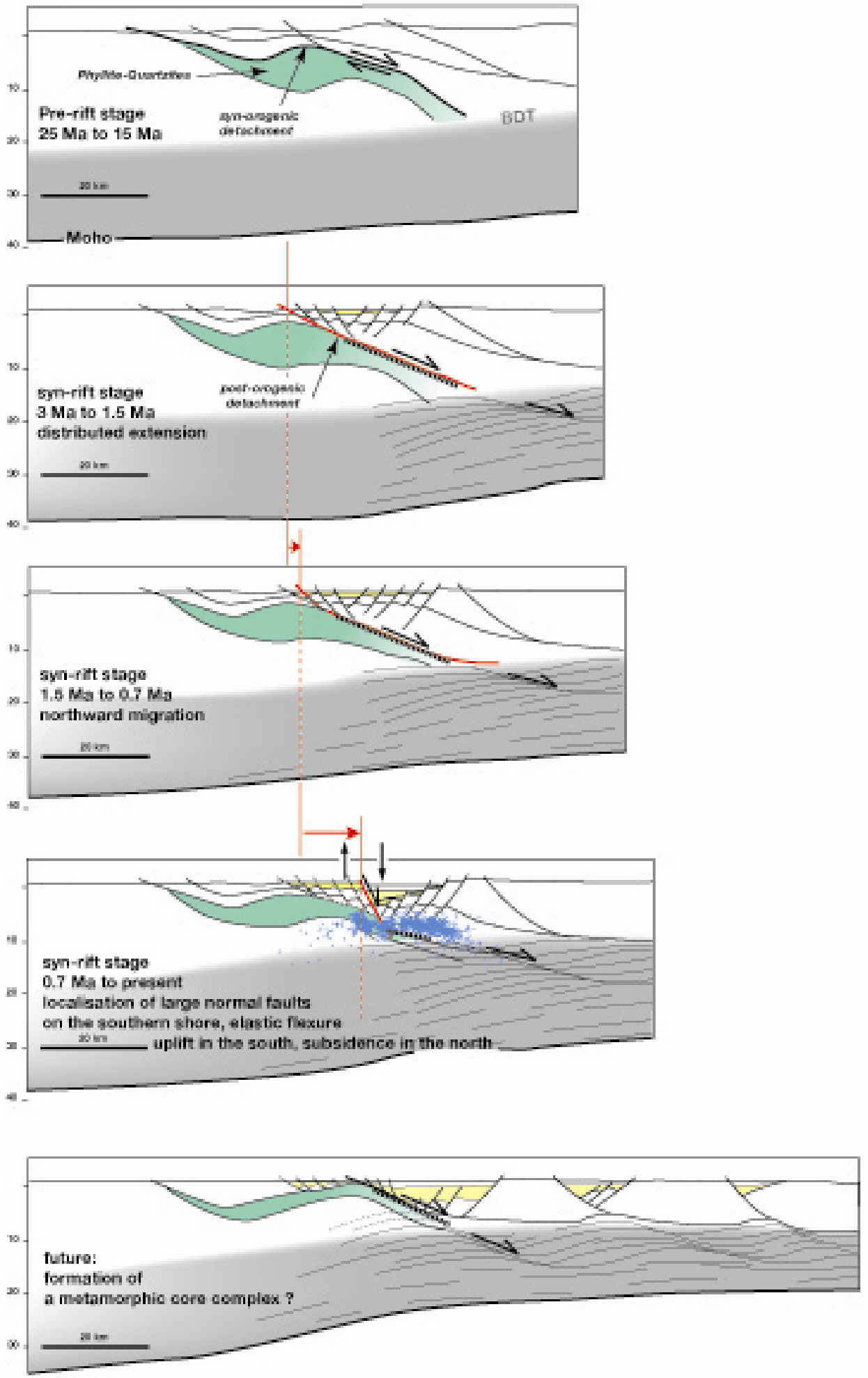

${ }^{*} \mathrm{~S}$

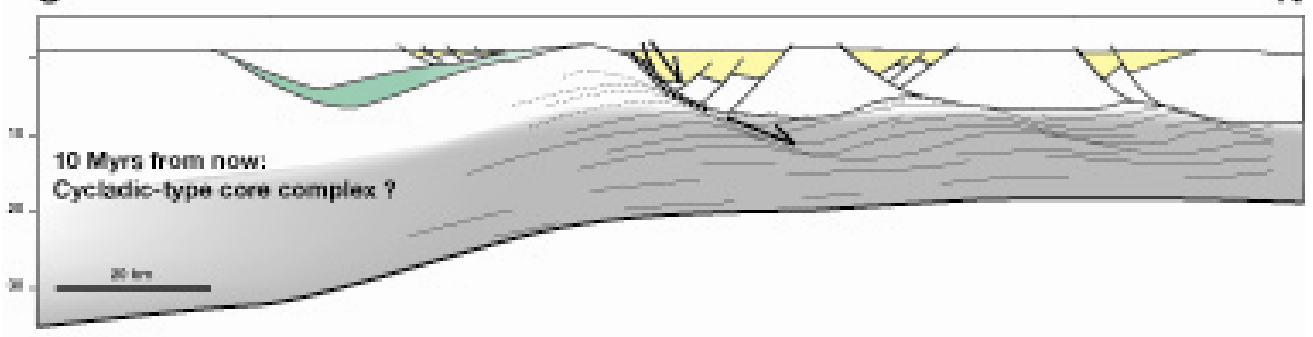


